\title{
Crude Oil Moments and PNG Stock Returns
}

\author{
April 24, 2014
}

\begin{abstract}
We examine the risk-neutral moments of crude oil and their relationship to stock returns in the Petroleum and Natural Gas (PNG) industry. We find substantial overlaps in the association between returns and S\&P 500- and crude oil higher moments. Net of these overlaps, PNG stocks share a significant negative relationship with crude volatility and positive relationships with crude skewness and kurtosis. Large cap stocks and those with a history of hedging exhibit negative loadings on crude volatility. However, after controlling for S\&P 500- and crude oil returns and their risk-neutral moments, there is little evidence that PNG stocks systematically and significantly price either S\&P 500- or crude oil volatility. We document a weak pricing of crude skewness, but find no evidence for the pricing of the implied higher moments of market returns.
\end{abstract}

Keywords: Risk Neutral Moments, Crude Oil, Petoleum and Natural Gas, Stock Returns

JEL Code: G13, G14 


\section{Introduction}

The purpose of this paper is to examine the relationship between the risk-neutral moments of crude oil returns and stock returns in the Petroleum and Natural Gas (PNG) industry. Recent studies indicate that aggregate market volatility and skewness are priced factors in the cross-section of stocks, inconsistent with CAPM intuition, but keeping in focus the importance of market behavior to expected returns (Ang et al. (2006), Yang et al. (2010), and Chang et al. (2013)). The theoretical arguments for pricing aggregate volatility, which has its basis on Merton's (1973) ICAPM and related extensions by Campbell $(1993,1996)$ and Chen $(2003)$, center on the actions of risk-averse agents who purchase volatility to guard against major market declines. Implicitly, these arguments make the pricing of lesser, business-level or product-level return moments redundant. We assess whether this is indeed the case by conducting an industry-level, focused study of the relationship between stock returns and crude oil moments while controlling for market-wide volatility and higher moment risk. To the best of our knowledge, this paper represents the first investigation of the pricing of higher moment risk of crude oil in stocks that are directly related to the commodity. In other words, our study represents the first examination of higher moments risk at the product level.

Ang et al. (2006) show that stocks with high sensitivity to market volatility, as implied by the S\&P 100 VIX, earn low average returns, indicating a negative price for market volatility. Ang et al. (2006) do not consider skewness and kurtosis risks in their analysis. Chang et al. (2013) extend this research and report that stocks that are most negatively related to market skewness, implied by S\&P 500 options, earn the highest returns in subsequent months. Notably, the cross-sectional evidence documented for skewness are much stronger than those for volatility and kurtosis. The authors find these results to hold even after controlling for several factors including market excess returns, size, book-to-market and momentum. Yang et al. (2010) show that aggregate volatility, proxied by either stock market- or bond market volatility, commands a negative ex ante 
risk premium. The authors find this result to hold for the U.S. as well as the U.K.

The theoretical arguments for the pricing of aggregate market volatility are focused on portfolio-level hedging effects. These arguments are summed up in Bakshi and Kapadia (2003) and Ang et al. (2006), and may be further summarized as follows: investors who wish to guard against major market declines will pay a premium to own assets whose returns covary positively with market volatility, since realized volatility is highest when markets are falling (French et al. (1987) and Whaley (2009)). The symptom/outcome of the suggested behavior is that Black-Scholes or model-free implied volatility on stock options is systematically higher than realized volatility (Jackwerth and Rubinstein (1996)). The notion that investors require a premium to bear variance risk (or variance risk premium) has been documented by Carr and Wu (2009) for stocks, and Prokopczuk and Wese Simon (2013) for commodities. Similarly, a dynamically hedged portfolio of index puts and stocks significantly underperforms the risk-free rate (Bakshi and Kapadia (2003)), indicating a premium is paid over the theoretical price of options. Ultimately, the investor behavior that leads to a negative price of aggregate volatility is that assets with high loadings on market volatility are favored, raising their prices and suppressing their subsequent returns. Ang et al. (2006) confirm this phenomenon by finding that stocks with high exposure to volatility exhibit lower average returns when compared with stocks with low sensitivity to volatility. $!^{1}$

If aggregate volatility matters in this way, should we expect to see similar arguments play out at the product- or business levels? For instance, would investors pay a premium for those PNG companies that have a greater (more positive) loading on the volatility in oil prices? In a recent paper, Ramos and Veiga (2011) document that oil prices have a positive impact on the returns of the oil and gas industry. However, as indicated earlier,

\footnotetext{
${ }^{1}$ The arguments for pricing market skewness are not as well developed. Negative skewness may be symptomatic of information asymmetry or credit/borrowing constraints accompanying large market drops (Yan (2005)). Therefore, a case may be made that uniformed investors will prefer stocks with inverse loadings on skewness. This narrative would be inconsistent with the evidence on Chang et al. (2013), and Yang, Zhou, and Wang (2010). These authors make the case for a negative price of skewness.
} 
none of the above theoretical arguments will admit the pricing of product-level volatility, since the purchase of Market volatility to guard against Marketwide declines should make redundant purchasing of further business-level volatility 2 . However, the pieces of evidence that are often employed to highlight the importance of systematic volatility also seem to be relevant at the asset-level. For instance, just as there is evidence that volatility risk premium causes implied volatility of S\&P 500 to be greater than its realized volatility, there is similar evidence that implied volatility of most assets (for example, currencies, interest rates, credit instruments) is greater than their realized volatility (Poon and Granger (2003)). Is this part of the evidence that volatility premium is also suffered in other assets, perhaps by undiversified investors? If so, following the above arguments, the undiversified investor would have a preference for stocks within the industry that have the highest factor loadings on the product's volatility, increasing their prices and depressing future returns. We expect this paper to shed some light on this debate.

We study the potential role of crude oil higher-moments in PNG returns in two ways. First, we document a strong relationship between PNG stock returns and implied volatility, skewness and kurtosis of WTI crude oil and the S\&P 500 index (proxy for the market) across firm-specific factors such as firm size and whether or not the firm hedges. This allows us to evaluate the nature and direction of the relationship between stock returns and higher return moments both at the aggregate level and at the individual business level. It also enables us to map the moment-loadings for crude and the aggregate Market, and assess the overlap between them. Second, we undertake an exercise to establish whether the moment-loadings are important to subsequent PNG stock returns. This allows us to address the questions on the pricing of higher moments - are crude volatility

\footnotetext{
${ }^{2}$ Further to this argument of redundancy, there are theoretical grounds and empirical evidence that correlations among assets rise during severe market downturns (Yuan (2005), J.P. Morgan (2011)).

${ }^{3}$ It should be noted that the upward bias in implied volatility does not necessarily imply a volatility premium. The upward bias could also arise due to the misspecification of the options model itself (Doran and Ronn (2005)), measurement errors of the options features (Christensen and Prabhala (1998) and Ederington and Guan (2002)), or Bayesian-learning processes arising within a general equilibrium model for asset prices (Guidolin and Timmermann (2003)).
} 
and skewness priced factors for PNG stocks? Is the pricing of crude moments similar to that found in for market-wide moments. More generally, to what extent is the pricing of higher market moments accompanied with similar pricing of hitherto unexplored business industry-level variables?

We choose to focus on the PNG industry for some important reasons. First, the industry is a near pure-play candidate in the assessment of the pricing of product moments, namely the sensitivity to the moments of crude oil returns. ${ }^{4}$ If crude volatility is priced for the same reasons put forth for market volatility (i.e., the hedging preference of investors), it should be evident most of all in PNG stock returns. For instance, PNG stocks with high positive loadings on crude volatility might be preferred by undiversified investors who wish to guard against the negative effects associated with increased crude oil volatility $\left.\right|^{5}$ Second, crude oil and the aggregate market themselves are known to be related, so that we are able to put the notion that market-moments are singularly important through a stringent test. For instance, if there is evidence that the loadings on the market moments are important despite controls for crude moments, one could argue more forcefully that Market moments are priced by PNG stocks. Furthermore, if there is evidence that the loadings on crude moments are important, this could open the door to more generally examine the relevance of product-level moments in the cross-sectional pricing of stock returns. Finally, there is a liquid and well established options market on crude oil contracts, making the study of higher business-specific moments possible. Other commodities - copper, gold, and wheat, among others - also have fairly liquid options markets, but there are relatively few companies with exclusive ties to them. For instance, in 2011, there were 149 publicly traded firms in the PNG industry and there were as many as 225 PNG firms in 1996.

\footnotetext{
${ }^{4}$ The profitability of the PNG firms is known to be impacted by crude returns (see Jin and Jorion, (2006)). While many energy companies hedge the risk of crude oil, they are frequently only partially hedged and often employ strategies such as collars, where profits are still dependent on price movements.

${ }^{5}$ Increased volatility is commonly associated with deteriorating fundamentals, so that favoring stocks that perform better during increased crude volatility might represent an act of diversification.
} 
Our empirical study spans 1996-2011. We employ the methodology in Bakshi and Kapadia (2003) and Bakshi et al. (2003) to obtain risk-neutral moments derived from options on WTI crude futures and the S\&P 500 index. As noted in Chang et al. (2013), these moments are forward looking and conditional in that they are extracted from options and corresponding stock prices on a daily basis ${ }^{6}$ The extracted moments have strong autoregressive tendencies similar to those found in Chang et al. (2013). Consequently, we employ appropriately conditioned innovations of moments in our empirical exercises. We employ daily stock price and quarterly financial statements' data for the universe of publicly traded U.S. corporations in the PNG industry. To guard against biases inflicted by outlying sensitivities, our analysis is based on the average parameters obtained from daily time-series regressions run on individual companies on a quarterly basis.

The findings of this study may be summarized as follows. (1) Daily S\&P 500 implied volatility innovations are positively correlated with those of crude oil. This is generally consistent with the evidence relating to the role of crude oil price movements in the stock market and the larger economy (Jones and Kaul (1996), Kilian (2008) and Hamilton (1983)). On the other hand, there is a relative lack of daily cross-correlation for skewness and kurtosis, although there are some common temporal tendencies, such as the relative instability of market higher moments and crude higher moments after 2003. (2) Excess returns of PNG stocks are significantly negatively related to crude volatility innovations, and positively related to crude skewness and kurtosis innovations. The stock returns are also positively related to S\&P 500 volatility. These results suggest that PNG stocks, on average, perform poorly (well) during days of increased crude (Market) volatility. (3) Company size matters in how PNG stocks returns are related to crude oil moments. The

\footnotetext{
${ }^{6}$ It can be determined from the tabulations in Poon and Granger (2003) and Poon (2005) that implied volatility outperforms standard- or ARCH-type volatility in forecasting realized volatility in the vast majority of studies that perform this comparison. Consistent with the evidence for financial assets, Chatrath, Hong, Ramchander and Wang (2013) find that crude oil model-free implied volatility has good forecasting power vis a vis realized volatility albeit with an upward bias.
} 
positive relationship between PNG stock returns and crude returns increases in company size, and the negative relationship between PNG stock returns and crude implied volatility becomes stronger with company size. (4) Stocks of PNG companies that hedge are more negatively related to crude volatility, possibly symptomatic of the positive relationship between hedging costs and volatility. On the other hand, stocks of PNG companies that do not hedge are more closely related to aggregate market volatility. (5) Despite the strong relationship between the contemporaneous PNG stock returns and S\&P 500and crude oil higher-moments, there is little evidence that they are priced factors. For instance, portfolios comprised of PNG stocks with the lowest (most negative) loading on crude volatility obtain month-ahead Carhart alphas that are statistically indistinguishable from those with the highest loadings. It is only when portfolios are based on the loadings of both, S\&P 500- and crude volatility jointly, we find weak indications of a negative price of volatility risk. This result is in contrast with prior work on wider cross-sections of stocks that find aggregate volatility to be a significantly and negatively priced factor. On the other hand, we do find some evidence of a positive price for crude skewness. Overall, the higher moments of crude are at least as important as those of the S\&P 500 for the pricing of PNG stocks.

The remainder of the paper is organized as follows. Section 2 describes the crude, S\&P 500, and PNG stock returns data. Section 3 provides a brief overview of the procedure for obtaining the model-free moments for crude and the S\&P 500. As these moments exhibit strong autoregressive patterns, the procedures for obtaining innovations of these moments are also discussed. Section 4 reports and discusses the results on the relationship between PNG stock returns and the crude and S\&P 500 moment innovations. Section 5 concludes the paper. 


\section{Data}

Our study employs end-of-day data for futures, stocks and options from January 1996 through December 2011. End-of-day options prices for WTI crude oil futures are obtained from the CME Group. Options prices for the S\&P 500 index are from the CBOE. The exercise styles for the WTI and S\&P 500 options are American and European, respectively. Data for the end-of-day options prices are used to estimate the risk-neutral higher moments. Since the markets for crude futures and their options are liquid and have identical trading hours, measurment error from non-synchronous trading is likely to be minimal. We form a continuous daily time series of crude oil futures prices by using near-term contract that switches to the next nearby contract when the former is 10 days from expiration. Using this rollover procedure minimizes the artificial jumps in the price series.

The summary statistics for the crude oil options and S\&P 500 employed in this study are presented in Table 1. Panel A shows that for crude oil, there are over two million observations fairly evenly divided across calls and puts. The mean moneyness, defined by the ratio of strike price to underlying price for puts and the ratio of underlying price to strike price for calls, is 0.86 for both calls and puts. The average days to expiration (Days) is 243 for calls and 246 for puts, and the options settlement prices range from $\$ 3.5$ to approximately $\$ 28$. Therefore, our sampling of calls and puts is fairly symmetric across moneyness, expiration, and prices. Panel B shows the corresponding statistics for the S\&P 500 options. Put options comprise more than $60 \%$ of the approximately 1 million observations. The average moneyness for calls and puts is 0.93 and 0.87 , respectively. The average days-to-expiration is 125 for calls and 123 for puts. The mean prices for calls and puts are $\$ 24.55$ and $\$ 18.50$, respectively.

\section{Insert Table 1 here}

We use the No. 30 (Petroleum and Natural Gas) of the Fama-French 48 industry 
definitions as our PNG industry definition. We assign each NYSE, AMEX, and NASDAQ stock to the PNG industry at the end of June of a particular year based on its four-digit SIC code at that time. Based on this definition, the PNG industry includes stocks with SIC code 1300 - 1389, 2900 - 2912 and 2990 - 2999. The PNG stock return data is from CRSP. After removing holidays, we have 4019 trading days in the sample. There are, on average, 177 companies over our sampling period 7

We also collect hedge related accounting information reported as a component in "Other Comprehensive Income" (OCI) for all PNG firms in our sample. This accounting item is obtained from COMPUSTAT. The accounting rule SFAS 133, released in June 1998, provides the guidelines for derivatives related accounting for corporations. Most firms adopted SFAS 133 at the beginning of the fiscal year 2001. For derivative transactions that are designated as hedging transaction exposure, the effective portion of the derivatives-related gains or losses are initially (in the current fiscal quarter) reported in OCI and are later reclassified into earnings when the forecasted transaction affects earnings. The ineffective portion of gains or losses is reported in earnings immediately. The OCI gains or losses are aggregated in the "Accumulated Other Comprehensive Income" (AOCI) and reported in the equity section of the balance sheet. A similar set of rules apply to the accounting of derivatives designated to hedge foreign exchange exposure. Whereas changes in AOCI may not fully reflect the effectiveness of the hedging schemes of a corporation, its absence in the financial statements of a mature corporation would most likely imply that the firm has no significant history of hedging transactions or currency exposures. We designate a firm as a non-hedging corporation if it has been in existence for at least one year and its AOCI derivatives gains/losses position is zero. On the other hand, the firm is designated as a hedging corporation if derivatives reported in the firm's

\footnotetext{
${ }^{7}$ The number of sampled firms drops from 225 in 1996 to 170 in 2002, due mostly to the hectic M\&A activity in the 1990s and early 2000s, including BP's acquisitions of Amoco (1998) and of ARCO (2000), Exxon's merger with Mobil (1999), Chevron's acquisition of Texaco (2001), and the merger of Conoco Inc. and Phillips Petroleum Company (2002). Beyond 2002, the sample remains relatively steady, ranging between 149 in 2011 to 169 in 2008.
} 
AOCI indicates gains or losses. Given the manner in which derivative transactions are reported by firms we assume that crude oil hedges account for the majority of derivatives gains or losses for PNG companies. We acknowledge that this is a far-from-perfect means to designate hedging companies, especially since we do not consider the degree to which

a firm is hedging. However, it is a relatively efficient means to obtain the sample of non-hedging firms. There is variation in the number of firms that may be categorized as hedging or non-hedging across the sample period. On average, we find about $44 \%$ of firms to hedge each quarter, ranging from 36\% in 2011Q3 to 53\% in 2003Q4, translating to 2315 quarterly observations for hedging firms and 2982 quarterly observations for non-hedgers. The FASB 133 guidelines were not permitted to be applied retroactively; therefore, our examination of the role of hedging in the moment sensitivity is restricted to $2002-2011$.

\section{Risk-Neutral Higher Moments}

The alternative efforts to extract the risk-neutral distribution from option prices is reviewed in Britten-Jones and Neuberger (2000) and Jiang and Tian (2005). Britten-Jones and Neuberger (2000) derive model-free implied volatility under the assumptions of returns following a diffusion process in an environment of zero dividends and risk-free rates. They define the model-free implied variance as:

$$
E_{0}^{F}\left[\int_{0}^{T}\left(\frac{d F_{t}}{F_{t}}\right)^{2}\right]=2 \int_{0}^{\infty} \frac{C^{F}(T, K)-\max \left(0, F_{0}-K\right)}{K^{2}} d K,
$$

where $E^{F}$ refers to expectation under the forward probability measure, $C^{F}(T, K)$ is the forward price of a call option with maturity $T$ and strike $K$, and $F_{0}$ is the forward price of the underlying.

The key building blocks in estimating the risk-neutral higher moments are described in Bakshi et al. (2003). The authors present an approach to extract the higher moments 
of the risk-neutral distribution from a set of out-of-the-money (OTM) options. ${ }^{8}$ The risk neutral volatility $\left(\sigma^{M F}\right)$, skewness $(S K E W)$, and kurtosis $(K U R T)$ extracted at time $t$ with horizon $\tau$ can be expressed, respectively, in terms of the fair values of the volatility contract, the cubic contract, and the quadratic contracts. The three contracts have the payoffs:

$$
H(S)= \begin{cases}R_{t, \tau}^{2} & \text { volatility contract } \\ R_{t, \tau}^{3} & \text { cubic contract } \\ R_{t, \tau}^{4} & \text { quadratic contract }\end{cases}
$$

where, $R_{t, \tau}=\ln \left[S_{t+\tau}\right]-\ln \left[S_{t}\right]$ is the $\tau$-period return. The fair values of the contracts are defined as

$$
\begin{aligned}
V_{t, \tau} & =E_{t}^{Q}\left[e^{-r \tau} R_{t, \tau}^{2}\right], \\
W_{t, \tau} & =E_{t}^{Q}\left[e^{-r \tau} R_{t, \tau}^{3}\right], \\
X_{t, \tau} & =E_{t}^{Q}\left[e^{-r \tau} R_{t, \tau}^{4}\right],
\end{aligned}
$$

where $r$ denotes the continuously compounded risk-free rate (assumed constant).

\footnotetext{
${ }^{8}$ Bakshi et al. (2003) derive implied moments using European options, but indicate that the derivations are equally applicable to American options.
} 
The four moments are expressed as

$$
\begin{aligned}
\mu_{t, \tau} & =E_{t}^{Q} \ln \left[\frac{S_{t+\tau}}{S_{t}}\right]=e^{r \tau}-1-\frac{e^{r \tau}}{2} V_{t, \tau}-\frac{e^{r \tau}}{6} W_{t, \tau}-\frac{e^{r \tau}}{24} X_{t, \tau}, \\
\sigma_{t, \tau}^{M F} & =\sqrt{E_{t}^{Q}\left[R_{t, \tau}^{2}\right]-\mu_{t, \tau}^{2}}=\sqrt{e^{r \tau} V_{t, \tau}-\mu_{t, \tau}^{2}}, \\
S K E W_{t, \tau} & =\frac{E_{t}^{Q}\left[\left(R_{t, \tau}-E_{t}^{Q}\left[e^{-r \tau} R_{t, \tau}\right]\right)^{3}\right]}{\left\{E_{t}^{Q}\left[\left(R_{t, \tau}-E_{t}^{Q}\left[e^{-r \tau} R_{t, \tau}\right]\right)^{2}\right]\right\}^{\frac{3}{2}}} \\
& =\frac{e^{r \tau} W_{t, \tau}-3 \mu_{t, \tau} e^{r \tau} V_{t, \tau}+2 \mu_{t, \tau}^{3}}{\left[e^{r \tau} V_{t, \tau}-\mu_{t, \tau}^{2}\right]^{\frac{3}{2}}} \\
K U R T_{t, \tau} & =\frac{E_{t}^{Q}\left[\left(R_{t, \tau}-E_{t}^{Q}\left[e^{-r \tau} R_{t, \tau}\right]\right)^{4}\right]}{\left\{E_{t}^{Q}\left[\left(R_{t, \tau}-E_{t}^{Q}\left[e^{-r \tau} R_{t, \tau}\right]\right)^{2}\right]\right\}^{2}} \\
& =\frac{e^{r \tau} X_{t, \tau}-4 \mu_{t, \tau} e^{r \tau} W_{t, \tau}+6 e^{r \tau} \mu_{t, \tau} 2 V_{t, \tau}-3 \mu_{t, \tau}^{4}}{\left[e^{r \tau} V_{t, \tau}-\mu_{t, \tau}^{2}\right]^{2}} .
\end{aligned}
$$

The contract's fair values are determined by spanning their payoffs via a portfolio of call and put options together with the asset and a risk-free bond. Thus, the values of $V_{t, \tau}, W_{t, \tau}$, and $X_{t, \tau}$ are linear combinations of out-the-money calls and puts, i.e.

$$
\begin{aligned}
V_{t, \tau}= & \int_{S_{t}}^{\infty} \frac{2\left(1-\ln \left[\frac{K}{S_{t}}\right]\right)}{K^{2}} C_{t, \tau}(K) d K \\
& +\int_{0}^{S_{t}} \frac{2\left(1+\ln \left[\frac{K}{S_{t}}\right]\right)}{K^{2}} P_{t, \tau}(K) d K, \\
W_{t, \tau}= & \int_{S_{t}}^{\infty} \frac{6 \ln \left[\frac{K}{S_{t}}\right]-3\left(\ln \left[\frac{K}{S_{t}}\right]\right)^{2}}{K^{2}} C_{t, \tau}(K) d K \\
& -\int_{0}^{S_{t}} \frac{6 \ln \left[\frac{K}{S_{t}}\right]+3\left(\ln \left[\frac{K}{S_{t}}\right]\right)^{2}}{K^{2}} P_{t, \tau}(K) d K,
\end{aligned}
$$




$$
\begin{aligned}
X_{t, \tau}= & \int_{S_{t}}^{\infty} \frac{12\left(\ln \left[\frac{K}{S_{t}}\right]\right)^{2}-4\left(\ln \left[\frac{K}{S_{t}}\right]\right)^{3}}{K^{2}} C_{t, \tau}(K) d K \\
& +\int_{S_{t}}^{\infty} \frac{12\left(\ln \left[\frac{K}{S_{t}}\right]\right)^{2}+4\left(\ln \left[\frac{K}{S_{t}}\right]\right)^{3}}{K^{2}} P_{t, \tau}(K) d K .
\end{aligned}
$$

The risk-neutral higher moments are conceptually appealing and it is theoretically straightforward to evaluate the quantity $V_{t, \tau}, W_{t, \tau}$, and $X_{t, \tau}$. However, the computations of these values is challenging in practice. For instance, since the right hand of Equation 1 involves an integral of option prices over an infinite range of strike prices, it can only be approximated 9 This study uses an approach similar to Bakshi et al. (2003) and Jiang and Tian (2005) to extract model-free risk-neutral higher moments. First, the data are cleaned by eliminating options that: (a) do not have bid or ask prices; (b) violate the boundary condition; (c) have price quotes less than $3 / 8$, as they are too close to tick size, and (d) are well in-the-money, specifically, calls with strikes less than $97 \%$ of the underlying prices and puts with strikes more than $103 \%$ of the price. Second, we compute the Black-Scholes (B-S) implied volatility for all the remaing options. Third, we fix the maturities and use the cubic spline (curve smoothing) technique to interpolate the moneyness, which is defined as strike/underlying-price, from 0.1 to 3.0. Thus, we smooth volatility curves for each of the observed maturities. Fourth, we fix the moneyness and interpolate fixed maturities to construct a smooth volatility curves along the maturities to obtain a smooth volatility surface. Fifth, we use cubic spline to find the implied volatility curve for the fixed maturity of 30 calendar-days from the smoothed surface. Sixth, we use the B-S equation to back out corresponding option prices. Finally, employing numerical integration techniques we compute the higher-order moments by using equations (5) to (7). Since there are only a limited number of strike prices and maturities that are traded, we use the extrapolation technique for the maximum and minimum strike prices

\footnotetext{
${ }^{9}$ For clarity, it is noted here that while the returns for crude oil and the S\&P 500 are from the respective markets themselves, the additional moments are estimated from options prices. Therefore, the moments span the physical as well as the options markets.
} 
and maturities as in Jian and Tian (2005). That is, the volatility function is assumed to be constant beyond the available range of strike prices and maturities.

Figure 1 and Figure 2 plot the daily returns and risk-neutral moments for S\&P 500 and WTI crude oil futures. Some similarities and differences are immediately evident. The volatility patterns appear to be closely related across crude and the aggregate stock market. Interestingly, the kurtosis for both stocks and oil is relatively range-bound and shows relatively less bias until 2003, at which point it becomes more variable for both assets. Also interesting is the drop-off in the kurtosis of both stocks and crude in 2009, even while the volatility was at its highest in both asset classes. The starkest difference in moments across the two assets is seen in the magnitude of the kurtosis - it is substantially higher for the stock market than it is for oil. Options data appears to suggest fewer jumps in oil prices than in the aggregate stock market.

\section{Insert Figure 1 here \\ Insert Figure 2 here \\ Insert Figure 3 here}

Chang et al. (2013) find considerable autocorrelation in the moments of the S\&P 500 and employ innovations (rather than levels) of volatility, skewness and kurtosis in their empirical work. We find similar patterns over our sample for both the S\&P 500 and crude oil. Figure 3 provides the autocorrelation functions for the raw-, first differenced, and $\operatorname{ARMA}(1,1)$-residual functions for crude oil ${ }^{10}$ A slow decay in the autocorrelations are noted for the three moments. Taking first differences makes the autocorrelation statistically insignificant (horizontal bands indicate $95 \%$ confidence intervals) for volatility, but not for the other two moments. For the latter, the $\operatorname{ARMA}(1,1)$ is found to be more appropriate. The AR(1) parameters for crude skewness and kurtosis are 0.970 and 0.921 . The MA(1) parameters for crude skewness and kurtosis are 0.485 and 0.592. A similar

\footnotetext{
${ }^{10} \mathrm{~A}$ similar argument for a positive price of crude volatility is that higher crude volatility will increase the PNG firms' cost of hedging, so that investors will sell PNG stocks based on deteriorating profit expectations.
} 
exercise is performed on the moments of the $\mathrm{S} \& \mathrm{P} 500$ index. The $\mathrm{AR}(1)$ parameters for S\&P 500 skewness and kurtosis are 0.973 and 0.966. The corresponding MA(1) parameters are 0.557 and 0.467 . Based on these results, our daily innovations for the two sets of moments are:

$$
\begin{array}{ll}
\text { Volatility: } & \Delta V_{S P, t}=V_{S P, t}-V_{S P, t-1}, \\
& \Delta V_{C, t}=V_{C, t}-V_{C, t-1} ; \\
\text { Skewness: } & \Delta S_{S P, t}=S_{S P, t}-0.973 \times S_{S P, t-1}+0.557 \times \Delta S_{S P, t-1}, \\
& \Delta S_{C, t}=S_{C, t}-0.970 \times S_{C, t-1}+0.485 \times \Delta S_{C, t-1} ; \\
\text { Kurtosis: } \quad \Delta K_{S P, t}=K_{S P, t}-0.966 \times K_{S P, t-1}+0.467 \times \Delta K_{S P, t-1}, \\
& \Delta K_{C, t}=K_{C, t}-0.921 \times K_{C, t-1}+0.592 \times \Delta K_{C, t-1} .
\end{array}
$$

Table 2 reports the summary statistics for the daily innovations in the two sets of higher moments. The average volatility changes for crude oil are about three times that of the S\&P 500, implying that the magnitude of the PNG stock return sensitivities to crudeand $\mathrm{S} \& \mathrm{P}$ volatility innovations are not directly comparable. Similar implications are noted in the differences across the means for the skewness and kurtosis innovations. The lower half of Table 2 reports Pearson- and rank-correlations (above diagonal). There is a very negative correlation between marketwide innovations in skewness and kurtosis $\left(\rho_{P}=\right.$ $\left.-0.66, \rho_{R}=-0.81\right)$. Both of those coefficients are statistically significantly different from zero at the $1 \%$ level of significance. Following this result, we further transform these two variables via an orthogonalization procedure similar to that in Chang et al. The most positive correlation is noted between the volatility innovations for crude and the S\&P $500\left(\rho_{P}=0.24, \rho_{R}=0.18\right)$. The positive correlation is consistent with the theory and evidence that asset correlations rise during stock market declines, when volatility is at its highest (e.g., Yuan (2005) and J.P. Morgan (2011) ${ }^{11}$ ). It is also consistent with the general evidence relating to the role of crude oil price movements in the stock market

\footnotetext{
${ }^{11}$ See Rise of cross-asset correlations, a report by J.P. Morgan Global Equity Derivatives \& Delta One Strategy Group on 16 May 2011.
} 
and the larger economy (Jones and Kaul (1996), Kilian (2008), Hamilton (1983)). The cross-correlations for skewness and kurtosis innovations are relatively small.

\section{Insert Table 2 here}

\section{$4 \quad$ PNG Stock Returns and Risk Neutral Moments}

\subsection{Crude Moment Sensitivities}

Our first set of regression results examine the relationship between PNG stock returns and crude oil moments. Encompassing regressions using daily data are estimated that take the general form,

$$
E R_{i, t}=\alpha+\beta_{1} E R_{M, t}+\beta_{2} R_{C, t}+\beta_{3} \Delta V_{C, t}+\beta_{4} \Delta S_{C, t}+\beta_{5} \Delta K_{C, t}+\varepsilon_{i, t},
$$

where $E R_{i, t}=R_{i, t}-r_{f, t}$ and $E R_{M, t}=R_{M, t}-r_{f, t}$ represent, respectively, the daily excess

returns of the $i^{\text {th }}$ stock and the excess return of Market, $r_{f, t}$ denotes the risk-free rate (one month treasury rate), and $\varepsilon_{i, t}$ is the regression error.

We note at the outset that our expectations on the loadings on the crude moments are only loosely predicated by prior theory and evidence on the returns versus highermoments relationships. Specifically, the theses on the "pricing" of higher moments have generally been based on the relationship of returns and the moments underlying these same returns. For instance, theory and evidence suggests that skewness be negatively priced, and kurtosis positively priced (e.g., Yang, Zhou and Wang (2010)) for stock returns. On the other hand, our analysis here is of the relationship PNG stock returns and the moments of crude oil returns, in effect making our analysis one for the "crossmarket" correspondence of returns and moments.

Table 3 reports the results from the estimation of equation (11). In Panel A, the coefficients and Newey-West t-statistics are from daily pooled time-series data spanning 
1996-2011. These pooled-data results are provided mostly for comparative purposes as our subsequent regression analysis is based on individual (stock-level) regressions. The beta for the PNG industry is slightly lower than 1.00 (Model 1), and the crudeoil beta for the industry is 0.37 (Model 2). The aggregate market and crude oil returns together explain only about $9 \%$ of the variation in PNG stock returns in the panel format (Model 3). As the PNG industry is comprised of both producers (drillers and other upstream companies) and consumers (refiners and other downstream companies) of oil, the relatively low crude oil beta should not be surprising. The coefficients on the higher moments show very high levels of statistical significance when evaluated without the S\&P 500 excess returns and crude returns, with a negative coefficient on volatility, and positive coefficients on skewness and kurtosis (Model 4). When the regression is estimated in its full form (Model 5), the coefficients on volatility and skewness innovations are reduced to -0.05 and 0.005 , and remain statistically significant. However, kurtosis is no longer significant. It is readily apparent that we need to control for the effects of aggregate returns and crude oil returns when evaluating the loadings on the higher moments. ${ }^{12}$

We consider the possibility that the results reported in Panel A are influenced by extreme outlying moments of stock returns. It is evident from Figures 1 and 2 there are extreme spikes in the risk-neutral skewness and kurtosis, especially for crude oil (e.g., in early 2005). To test for the influence of outliers, we discard observations associated with the steepest changes in crude moments. The results are not perceptively altered. In another attempt to reduce the influence of outliers, we estimate the encompassing regressions for each company for each calendar quarter using daily data. The coefficients and corresponding robust t-statistics and adjusted- $R^{2} \mathrm{~s}$ are then averaged over the 19962011 period. Panel B of Table 3 reports these statistics. Despite the substantially

\footnotetext{
${ }^{12}$ It is important to point out that the positive return-skewness relationship documented in this study is in contrast with other studies in the equity market literature that report a negative pricing for skewness. This finding may be attributed to the fact that, unlike other studies that examine the pricing behavior of asset returns on its own higher moments our analysis focuses on the cross-market relationship between stock returns and crude oil higher moments.
} 
lower number of observations in the quarterly regressions, the average adjusted- $R^{2} \mathrm{~s}$ are substantially higher for each regression. The average beta and crude beta are 0.85 and 0.33, lower than those from the pooled data (Model 1 and Model 2), and jointly, crude returns and Market excess returns explain 19\% of the variation in stock returns when evaluated over calendar quarters (Model 3). When controlling for the S\&P 500 and crude returns, statistically significant coefficient are obtained for each of the three higher moments (Model 5). Overall, the results in Table 1 provide strong indications that contemporary crude oil stock returns are related to crude oil volatility, skewness and kurtosis.

\section{Insert Table 3 here}

\subsection{Aggregate- and Crude Moment Sensitivities}

The results in Table 3 provide some indications of a statistically significant relationship between crude oil moments and PNG returns; however, they are from a specification that does not jointly consider the aggregate market risks. It is possible, for instance, that the appearance of the relationship between PNG returns and crude volatility is only a manifestation of the relation to $\mathrm{S} \& \mathrm{P} 500$ volatility. To gauge the magnitude of overlaps in aggregate- and crude moment sensitivities, Figure 4 presents pairs of moment coefficients, $\beta_{X}^{S P}$ and $\beta_{X}^{C}$, from the regressions

$$
\begin{aligned}
E R_{i, t} & =\alpha+\beta_{1} E R_{M, t}+\beta_{2} R_{C, t}+\beta_{X}^{S P} \Delta X_{S P, t}, \\
\text { and } E R_{i, t} & =\alpha+\beta_{1} E R_{M, t}+\beta_{2} R_{C, t}+\beta_{X}^{C} \Delta X_{C, t},
\end{aligned}
$$

where $X$ takes values $V, S$,or $K$ and thus $\Delta X_{S P, t}$ and $\Delta X_{C, t}$ refer to the innovations of the higher moments of S\&P 500 and crude oil, respectively. The coefficients are estimated on a company-by-company basis using daily data over calendar quarter. The functions in Panel A indicates that the sensitivity to the S\&P 500 volatility innovations 
is mostly positive and that to crude volatility innovations is mostly negative. However, the two coefficients appear to be temporally related during periods of relative calm, though unrelated (or even negatively related) over the financial crisis. The scatter plot further indicates a generally positive relationship in the sensitivities that is weakened by large outliers (correlation coefficient is 0.06). A similar pattern of a positive temporal relationship is suggested for sensitivities to skewness innovations in Panel B (though the correlation is higher at 0.23$)$. No obvious temporal relationship is noted for the kurtosis sensitivities. Overall, the patterns in Figure 4 suggest that the sensitivities to crude and aggregate moments may share some common tendencies, especially for volatility and skewness. Therefore, the remaining tests jointly admit both aggregate market and crude oil moments.

\section{Insert Figure 4 here}

The comparison of the aggregate- and crude moment-sensitivities is undertaken via regressions of the form,

$$
\begin{aligned}
E R_{i, t} & =\alpha+\beta_{1} E R_{M, t}+\beta_{2} R_{C, t}+\beta_{3} \Delta V_{S P, t}+\beta_{4} \Delta S_{S P, t} \\
& +\beta_{5} \Delta K_{S P, t}+\beta_{6} \Delta V_{C, t}+\beta_{7} \Delta S_{C, t}+\beta_{8} \Delta K_{C, t}+\varepsilon_{i, t}
\end{aligned}
$$

where the coefficients are obtained for each calendar quarter over the 1996-2011 sample period. The estimated coefficients, robust t-statistics and adjusted $R^{2}$ are averaged by (i) firm size, and (ii) whether or not the company hedges.

Table 4 reports results from equation (14) that are averaged by firm size. Following Fama and French (2008), PNG companies are classified as Micro Cap (stocks with Market capitalization below the $20^{\text {th }}$ NYSE percentile), Small Cap (stocks with Market capitalization between the $20^{t h}$ and $50^{t h}$ NYSE percentile), and Large Caps (stocks with Market capitalization above the $50^{\text {th }}$ NYSE percentile) based on their capitalization at the end of June. The results in Panel B are for Large Cap PNG stocks. When considered 
independently, innovations in marketwide skewness and kurtosis, and each of the crude moment innovations appear statistically significant to stock returns of large companies. On the other hand, the S\&P 500 moment-innovations are not statistically important to stock return of large PNG companies when considered jointly, whereas the stock returns remain significantly associated with higher moments at the product level. The results in Panel C, pertaining to Small Cap PNG companies, paint a slightly different picture there is a positive coefficient on the $\mathrm{S} \& \mathrm{P}$ volatility innovations and a negative coefficient on crude volatility when the moments are considered jointly (Model 3). For Micro-Caps, the loadings on crude and S\&P 500 volatility disappear when considered jointly. Overall, the results in Table 4 indicate substantial overlaps between the moment loadings for PNG stocks. It is evident from these results that any analysis of potential premiums relating to crude moments would require careful controls for overlapping potential premiums on aggregate moments.

It is apparent from the results in Tables 3 and 4 that PNG stock returns are strongly and negatively related to crude implied volatility. This is especially true for large-cap stocks. It may be useful to consider this negative relationship in context of the potential investment opportunity in crude volatility. In this regard Guo et al. (2013), in their assessment of the time-varying risk-return tradeoff in stocks, show that their proxy for investment opportunities has a negative loading in the cross-sectional return regression. The authors suggest that the (common) evidence of countercyclicality in the risk-return tradeoff may be closely related to the changes in investment opportunities, rather than to changes in risk aversion. In that sense, crude volatility may represent an additional factor (or proxy for an investment opportunity) that explains the time variation in the risk-return tradeoff in PNG stocks. We do not explore this possibility further in the current paper.

Insert Table 4 here 
Table 5 reports results from equation (14) that are averaged by whether or not a PNG firm has a history of hedging based on the "Accumulated Other Comprehensive Income" (AOCI) derivatives gains/losses. The results in Panel A indicate large loadings on S\&P 500 volatility innovations for stocks of non-hedging firms. The market volatility sensitivity coefficient remains fairly stable across the alternate specifications (Model 1 and Model 3). This result is somewhat puzzling in that one should expect unhedged firms to be generally more exposed to market downturns as well. A plausible explanation is that PNG firms that are unhedged to crude oil shocks are the most likely to benefit from the spikes in crude prices, which often are accompanied with higher Market volatility. Non-hedging firms also show relatively little sensitivity to crude volatility innovations, but positive sensitivity to innovations in crude skewness and kurtosis. The results in Panel B are for hedging PNG stocks, and indicate substantially smaller loadings on S\&P 500 volatility innovations and significantly negative loadings on crude volatility innovations. A possible explanation for the negative sensitivity to crude-volatility observed in hedging PNG stocks may be that increased volatility imposes further costs in hedging. Nonetheless, the result that hedging firms are not any less sensitive to the moments of crude as compared to non-hedging firms is inconsistent with the general findings in Jin and Jorion (2006). It is tempting to suggest that our hedging (non-hedging) designation is capturing another important firm-specific factor:- firm-size. For instance, it may be that hedging (non-hedging) firms are mostly large (small) firms, so the that results in Table 5 is mostly to do with firm-size designations. An examination of the average market-values indicates that this is the case. The means of the hedging and non-hedging firms are $\$ 1.621$ billion and 276 million, respectively. That is, on average, the market value of a hedging firm is about 5.9 the size of a non-hedging firm. We leave further reconciliation of the hedging/no-hedging results to another study.

\section{Insert Table 5 here}




\subsection{The Pricing of Aggregate- and Crude Oil Volatility}

Traditional tests on the pricing of the market moments are based on the performance of portfolios constructed on the assets' loadings on the moments (e.g., Ang et al. (2006) and Chang et al. (2013)). Specifically, a negative volatility premium is implied when portfolios with high (positive) loadings on market volatility obtain relatively low returns in future periods. Similarly, a positive premium on volatility would be indicated if portfolios with low (negative) loadings on volatility subsequently earn relatively low returns in the future.

In a framework that incorporates controls for both, equity market returns and crude oil returns, we first establish volatility loadings for each company over each calendar month in the sample. In other words, the factor loadings are estimated using one-month intervals of daily data from the following regressions ("univariate"):

$$
\begin{aligned}
& E R_{i, t}=\alpha+\beta_{1} E R_{M, t}+\beta_{2} R_{C, t}+\beta_{V}^{S P} \Delta V_{S P, t}+\varepsilon_{i, t}, \\
& E R_{i, t}=\alpha+\beta_{1} E R_{M, t}+\beta_{2} R_{C, t}+\beta_{V}^{C} \Delta V_{C, t}+\varepsilon_{i, t},
\end{aligned}
$$

or ("multivariate"):

$$
\begin{aligned}
E R_{i, t} & =\alpha+\beta_{1} E R_{M, t}+\beta_{2} R_{C, t}+\beta_{3} \Delta V_{S P, t}+\beta_{4} \Delta S_{S P, t} \\
& +\beta_{5} \Delta K_{S P, t}+\beta_{6} \Delta V_{C, t}+\beta_{7} \Delta S_{C, t}+\beta_{8} \Delta K_{C, t}+\varepsilon_{i, t} .
\end{aligned}
$$

For every calendar month, firms are sorted into two sets of quintiles that are based on the loadings on S\&P 500 index and crude volatility, $\beta_{S P}$ and $\beta_{C}$. Value-weighted portfolios are then formed using these sorted companies. For each of these portfolios, we compute the Jensen alphas of each quintile portfolio with respect to the Carhart fourfactor model augumented by the crude oil futures return $\left(R_{C}\right)$ by running time-series regression of post-ranking (forward) daily excess returns on daily $E R_{M}$ (Excess Return of 
the Market), $S M B$ (Small Minus Big), $H M L$ (High Minus Low), $U M D$ (Momentum) ${ }^{13}$ and $R_{C}$. The daily alphas are multiplied by 21 to obtain monthly (\%) alphas. Post-ranked monthly portfolios returns are similarly obtained from daily returns.

The results of this exercise are reported in Table 6. The portfolios are presented from the lowest (most negative) to the highest loadings on volatility. In Panel A (the "univariate" case), the average crude oil volatility loadings exhibit a fairly symmetric range, from -1.05 to +1.07 . Interestingly, the crude volatility betas show substantially larger variability when obtained from the multivariate case, with loadings ranging from -1.39 to +1.57 . Similar patterns are observed in Panel B, which provides for the portfolio performances based on the S\&P 500 volatility loadings. Here we see a wide range for volatility loadings in the univariate case, of -1.85 and +1.92 , and even wider range in the multivariate case: -2.70 and +2.57 . It appears that the collinearity in the moments does influence the magnitude of the loadings to a large extent. For this reason, we place more emphasis on the results from the univariate case.

The results in Table 6 do not indicate that PNG stocks systematically price the volatility of the S\&P 500 or crude oil. Keeping with the results for the univariate case, the average month-ahead returns in Panel A fail to indicate a systematic pattern. For instance, although the returns are the highest for Portfolio 1, they are the lowest for Portfolio 2. The Carhart alpha does show a more systematic pattern: it is the highest for Portfolio 1, and drops off (becomes more negative) consistently from Portfolio 2 through 5. This pattern would suggest a negative pricing of crude volatility, wherein a premium is paid for stocks with the highest (most positive) volatility loadings. However, given the absence of statistical significance for the Carhart alphas we are unable to draw additional strong inferences on the pricing implications. An even weaker picture on the pricing of volatility emerges from the portfolios based on the S\&P 500 index volatility loadings. In Panel B (univariate case), we do not find returns to show a systematic pattern. The

\footnotetext{
${ }^{13}$ Daily values of the four factors are obtained from WRDS.
} 
Carhart alpha appears even more random - significantly negative for Portfolio 2, but positive for Portfolio 1 and Portfolio 5. As before, the differences between Portfolios 1 and 5 are not statistically significant. In summary, we do not find evidence of a "negative pricing" of aggregate market volatility, as has been noted in prior studies (e.g., Ang et al. (2006)). The weak pricing evidence may be attributed to fact that our results are based on a relatively narrow cross-section of stocks, and unlike prior work we also control for product level factors - i.e., the moments of crude oil.

To assess whether the findings in Table 6 are consistent across firm size, and to further assess the joint effects of the loadings to crude volatility and $\mathrm{S} \& \mathrm{P}$ volatility, we construct two more portfolios. In Portfolio A, only companies that have the lowest (most negative) loadings on crude volatility and S\&P volatility are admitted. Portfolio B admits only those companies that have the highest (most positive) loadings on crude volatility and S\&P volatility. The "univariate" specifications of (15) and (16) are employed to obtain the loadings on crude volatility and S\&P 500 volatility, separately. The month-ahead Carhart alphas from Portfolios A and B are reported in Table 7. If Market and crude volatilities are jointly negatively priced factors, we should find a relatively high (low) Carhart alpha for Portfolio A (B). The results point weakly negatively-priced volatilities: for the full sample of firms, the Carhart alpha for Portfolio A is about twice the size of that for Portfolio B. The pattern of weakly negative pricing of joint volatilities holds for large-caps and small-caps, but not for micro-cap stocks, for which we see volatilities to be positively priced. Overall, the evidence on the pricing of volatilities is weak. At best, we can say that aggregate volatility is a priced factor only when it is jointly considered alongside crude volatility, and vice versa.

\section{Insert Tables 6 and 7 here}




\subsection{The Pricing of Aggregate- and Crude Oil Skewness and Kurtosis}

We also analyze the data for the pricing of aggregate and crude oil skewness and kurtosis in PNG stocks. We follow the portfolio formation procedure detailed above, except that stocks are sorted on the loadings of skewness and kurtosis. In place of regressions (15) and (16), we use the regressions

$$
\begin{aligned}
& E R_{i, t}=\alpha+\beta_{1} E R_{M, t}+\beta_{2} R_{C, t}+\beta_{X}^{S P} \Delta X_{S P, t}+\varepsilon_{i, t}, \\
& E R_{i, t}=\alpha+\beta_{1} E R_{M, t}+\beta_{2} R_{C, t}+\beta_{X}^{C} \Delta X_{C, t}+\varepsilon_{i, t},
\end{aligned}
$$

where, $X$ refers to $S$ (for skewness) or $K$ (for kurtosis). The results for skewness and kurtosis are reported in Table 8. For brevity, only the results from the univariate case are presented.

The results in Panel A are for portfolios based on crude oil skewness loadings, which range from -0.30 to +0.30 . We find some evidence of a positive price for crude skewness. That is, PNG stock that have the most positive relationship with crude oil skewness perform the best in the month ahead. The Carhart alpha is the lowest for Portfolio 1 and the highest for Portfolio 5, with the difference in the alphas being statistically significant at the $10 \%$ significance level for a one-tailed test only (with p-value of $6.3 \%$ ). The evidence for the pricing of S\&P 500 skewness is weaker. Specifically, the Carhart alphas fail to exhibit significance or systematic pattern across the five PNG portfolios based on the S\&P skewness loadings. The results in Panel C and D are for PNG portfolios based on loadings on crude oil- and S\&P 500 kurtosis, respectively. Whereas the returns and Carhart alphas generally rise across the five portfolios in Panel D, the differences across the portfolios are not significant. The results in Panel D are even less indicative of systematic pricing behavior. In summary, while the $\mathrm{S} \& \mathrm{P} 500$ skewness and kurtosis do not appear to be priced factors there is some week evidence that PNG stocks price 
crude oil skewness.

\section{Insert Tables 8}

\section{Conclusion}

Recent evidence on the higher moments of stock indexes indicates that market volatility and skewness are priced factors. Specific to volatility, stocks with the most positive loadings on index-options implied volatility are found to earn the lowest subsequent returns, implying a negative price for Market volatility. In this paper we examine whether the risk-neutral higher moments of crude are important in a similar fashion for stocks in the PNG industry. Effectively, this paper represents an industry-specific investigation into the importance of product-level higher moments on contemporaneous and future stock returns.

Employing daily options and stock price data from 1996 through 2011, we establish that the moments of WTI crude oil are distinct from those of the aggregate market, proxied by the S\&P 500 index. For instance, crude volatility innovations are much larger than those of the market, and the aggregate market exhibits more (negative) skewness. However, we also find similarities in their respective autoregressive behaviors, and conduct our empirical analysis on ARMA transformed moments of the S\&P 500 index and crude oil. We find returns of PNG stocks to be related to higher moments in significant ways - PNG stocks are negatively related to crude volatility innovations and positively related to crude skewness- and kurtosis innovations. Notably, the relationship between PNG stock returns and the S\&P 500 moments is not as strong.

Further, we examine whether crude volatility is a priced factor as implied by the relationship between the loadings on crude volatility innovations and subsequent stock returns. We fail to find evidence that would suggest that either the S\&P 500 index or crude oil volatility is a priced factor. At best, we can conclude that the S\&P 500 and 
crude volatility are jointly and weakly priced factors. We also find some evidence of a positive pricing of crude skewness, but no similar evidence for S\&P 500 skewness. From a pricing standpoint it appears that crude higher moments are at least as important to PNG stock returns as are aggregate higher moments.

It must be noted that our sample is limited to PNG corporations with common cyclicals and relatively homogenous market and business-specific innovations. Therefore, our results documenting the lack of relationship between PNG returns and aggregate higher moments should not be treated as evidence against prior studies that find marketwide volatility and skewness to be important to a wider cross-section of returns. Nonetheless, the study does not rule out the possibility that product level moments are also important priced factors. 


\section{References}

[1] Ang, A., Hodrick, R.J., Xing, Y., and Zhang, X. (2006). "The Cross-section of Volatility and Expected Returns." Journal of Finance 61(1): 259-299.

[2] Bakshi, G. and Kapadia, N. (2003). "Delta-hedged Gains and the Negative Market Volatility Risk Premium." Review of Financial Studies 16(2): 527-566.

[3] Bakshi, G., Kapadia, N., and Madan, D. (2003). "Stock Return Characteristics, Skew Laws, and Differential Pricing of Individual Equity Options." Review of Financial Studies 16(1): 101-143.

[4] Britten-Jones, M., and Neuberger, A. (2000). Option Prices, Implied Price Processes, and Stochastic Volatility." Journal of Finance 55(2): 839-866.

[5] Campbell, J.Y. (1993). "Intertemporal Asset Pricing without Consumption Data." American Economic Review 83(3): 487-512.

[6] Carr, P. and Wu, L. (2009). "Variance Risk Premiums" Review of Financial Studies, 22(3): 1311-1341.

[7] Campbell, J.Y. (1996). "Understanding Risk and Return." Journal of Political Economy 104(2), 298-345.

[8] Chang, B.Y., Christoffersen, P., and Jacobs, K. (2013). "Market Skewness Risk and the Cross Section of Stock Return." Journal of Financial Economics 107(1), 46-68.

[9] Chatrath, A., Miao, H., Ramchander, S., and Wang, T. (2013). "Risk Neutral Moments and Crude Oil Returns." Colorado State University Working Paper.

[10] Chen, J. (2003). "Intertemporal CAPM and the Cross Section of Stock Returns." Unpublished working paper. University of Southern California, Los Angeles, CA.

[11] Chernov, M. (2007). "On the Role of Risk Pemia in Volatility Forecasting." Journal of Business and Economic Statistics 25(4): 411-426.

[12] Christensen, B. and Prabhala, N. (1998). "The Relation between Implied and Realized Volatility." Journal of Financial Economics 50(1): 125-150.

[13] Christie, A.A. (1982). "The Stochastic Behavior of Common Stock Variances - Value, Leverage and Interest Rate Effects." Journal of Financial Economics 10(4): 407-432.

[14] Coval, J.D. and Shumway, T. (2001). "Expected Option Returns." Journal of Finance 56(3): 983-1009.

[15] Doran, J. and Ronn, E. (2005). "The Bias in Black-Scholes/Black Implied Volatility: an Analysis of Equity and Energy Markets." Review of Derivatives Research 8(3): 177-198. 
[16] Ederington, L. and Guan, W. (2002). "Is Implied Volatility an Informationally Efficient and Effective Predictor of Future Volatility?" Journal of Risk 4: 29-46.

[17] Fama, E.F., and French, K.R. (1992). "The Cross-section of Expected Stock Returns." Journal of Finance 47(2): 427-465.

[18] Fama, E.F., and French, K.R. (2008). "Dissecting Anomalies." Journal of Finance 63(4): 1653-1678.

[19] French, K.R., Schwert, G.W., and Stambaugh, R.F. (1987). "Expected Stock Returns and Volatility." Journal of Financial Economics 19(1): 3-29.

[20] Guidolin, M. and Timmermann, A. (2003). "Option Prices under Bayesian Learning: Implied Volatility Dynamics and Predictive Densities." Journal of Economic Dynamics and Control 27(5): 717-769.

[21] Guo, H., Wang, Z., and Yang, J. (2013). "Time-Varying Risk-Return Tradeoff in the Stock Market," Journal of Money, Credit and Banking 45(4), 623-650.

[22] Hamilton, J.D. (1983). "Oil and the Macroeconomy since World War II." Journal of Political Economy 91(2): 228-248.

[23] Hentschel, L. (2003). "Errors in Implied Volatility Estimation." Journal of Financial and Quantitative Analysis 38(4): 779-810.

[24] Heston, S. (1993). "A Closed-form Solution for Options with Stochastic Volatility with Applications to Bond and Currency Options." Review of Financial Studies 6(2): 327-343.

[25] Jackwerth, J. and Rubinstein, M. (1996). "Recovering Probability Distributions from Option Prices." Journal of Finance 51(5): 1611-1631.

[26] Jiang, G.J., and Tian, Y.S. (2005). "Model Free Implied Volatility and its Information Contents." Review of Financial Studies 18(4): 1305-1342.

[27] Jin, Y.B. and Jorion, P. (2006). "Firm value and hedging: Evidence from U.S. oil and gas producers." Journal of Finance, 61(2): 893-919.

[28] Jones, C.M., and Kaul, G. (1996). "Oil and the Stock Markets." Journal of Finance 51(2): 463-491.

[29] Kilian, L. (2008). "Exogenous Oil Supply Shocks: How Big Are They and How Much Do They Matter for the U.S. Economy?" Review of Economics and Statistics 90(2): 216-240.

[30] Merton, R.C. (1973). "An Intertemporal Capital Asset Pricing Model." Econometrica 41(5): 867-887.

[31] Poon, S. and Granger, C. (2003). "Forecasting Volatility in Financial Markets: A Review." Journal of Economic Literature 41(2): 478-539. 
[32] Prokopczuk, M. and Simer, C.W. (2013): Variance Risk Premia in Commodity Markets, WFA 2013 Meetings Paper.

[33] Ramos, S.B., and Veiga, H. (2011). "Risk factors in oil and gas industry returns: International evidence." Energy Economics, 33(3): 525-542.

[34] Whaley, R.E. (2009). "Understanding the VIX." The Journal of Potfolio Management 35(3): 98-105.

[35] Yang, J., Zhou, Y., and Wang, Z. (2010). "Conditional Co-skewness in Stock and Bond Markets: Time Series Evidence," Management Science, 56(11): 2031-2049.

[36] Yuan, K. (2005). "Asymmetric Price Movements and Borrowing Constraints: A Rational Expectations Equilibrium Model of Crises, Contagion, and Confusion." Journal of Finance 60(1): 379-411. 


\section{Table 1: Statistics of Final Sample of Options Used to Calculate the Mo- ments}

This table reports the summary statistics of the final sample of options used to calculate the crude oil and S\&P 500 high moments. Money(ness) is defined as the ratio of strike price over underlying futures price for puts and the ratio of underlying futures prices over strike price for calls. Thus, the smaller the moneness, the more out of money the options.

\begin{tabular}{|c|c|c|c|c|c|}
\hline Type & Statistics & $\begin{array}{l}\text { Strike } \\
\text { Price }\end{array}$ & Money & $\begin{array}{l}\text { Days to } \\
\text { Maturity }\end{array}$ & $\begin{array}{l}\text { Settlement } \\
\text { Price }\end{array}$ \\
\hline \multicolumn{6}{|c|}{ Panel A. Options on Crude Oil Futures } \\
\hline $\begin{array}{l}\text { Call } \\
(\mathrm{N}=1011770)\end{array}$ & $\begin{array}{l}\text { Min } \\
\text { Mean } \\
\text { Max } \\
\text { Std }\end{array}$ & $\begin{array}{r}10.50 \\
82.78 \\
199.50 \\
36.90\end{array}$ & $\begin{array}{l}0.29 \\
0.86 \\
1.03 \\
0.14\end{array}$ & $\begin{array}{r}1 \\
243 \\
730 \\
179\end{array}$ & $\begin{array}{r}0.38 \\
3.54 \\
27.22 \\
3.29\end{array}$ \\
\hline $\begin{array}{l}\text { Put } \\
(\mathrm{N}=1034917)\end{array}$ & $\begin{array}{l}\text { Min } \\
\text { Mean } \\
\text { Max } \\
\text { Std }\end{array}$ & $\begin{array}{r}2.50 \\
61.32 \\
150.00 \\
25.87\end{array}$ & $\begin{array}{l}0.08 \\
0.86 \\
1.03 \\
0.12\end{array}$ & $\begin{array}{r}1 \\
246 \\
730 \\
174\end{array}$ & $\begin{array}{r}0.38 \\
3.51 \\
28.69 \\
3.19\end{array}$ \\
\hline $\begin{array}{l}\text { Total } \\
(\mathrm{N}=2046687)\end{array}$ & $\begin{array}{l}\text { Min } \\
\text { Mean } \\
\text { Max } \\
\text { Std }\end{array}$ & $\begin{array}{r}2.50 \\
71.93 \\
199.50 \\
33.56\end{array}$ & $\begin{array}{l}0.08 \\
0.86 \\
1.03 \\
0.13\end{array}$ & $\begin{array}{r}1 \\
244 \\
730 \\
176\end{array}$ & $\begin{array}{r}0.38 \\
3.52 \\
28.69 \\
3.24\end{array}$ \\
\hline \multicolumn{6}{|c|}{ Panel B. Options on S\&P 500 Index } \\
\hline $\begin{array}{l}\text { Call } \\
(\mathrm{N}=411494)\end{array}$ & $\begin{array}{l}\text { Min } \\
\text { Mean } \\
\text { Max } \\
\text { Std }\end{array}$ & $\begin{array}{r}585.00 \\
1243.18 \\
2000.00 \\
228.42\end{array}$ & $\begin{array}{l}0.42 \\
0.93 \\
1.03 \\
0.08\end{array}$ & $\begin{array}{r}1 \\
125 \\
730 \\
112\end{array}$ & $\begin{array}{r}0.38 \\
24.55 \\
214.88 \\
27.38\end{array}$ \\
\hline $\begin{array}{l}\text { Put } \\
(\mathrm{N}=640272)\end{array}$ & $\begin{array}{l}\text { Min } \\
\text { Mean } \\
\text { Max } \\
\text { Std }\end{array}$ & $\begin{array}{r}200.00 \\
1018.84 \\
1610.00 \\
241.36\end{array}$ & $\begin{array}{l}0.16 \\
0.87 \\
1.03 \\
0.13\end{array}$ & $\begin{array}{r}1 \\
123 \\
730 \\
114\end{array}$ & $\begin{array}{r}0.38 \\
18.40 \\
153.70 \\
21.39\end{array}$ \\
\hline $\begin{array}{l}\text { Total } \\
(\mathrm{N}=1051766)\end{array}$ & $\begin{array}{l}\text { Min } \\
\text { Mean } \\
\text { Max } \\
\text { Std }\end{array}$ & $\begin{array}{r}200.00 \\
1106.61 \\
2000.00 \\
260.50\end{array}$ & $\begin{array}{l}0.16 \\
0.89 \\
1.03 \\
0.12\end{array}$ & $\begin{array}{r}1 \\
124 \\
730 \\
113\end{array}$ & $\begin{array}{r}0.38 \\
20.81 \\
214.88 \\
24.10\end{array}$ \\
\hline
\end{tabular}




\section{Table 2: Daily Statistics of Market and Crude Oil Moments, 1996-2011}

Risk-neutral moments are obtained daily using WTI crude oil and S\&P 500 options. $\Delta V_{S P}$ and $\Delta V_{C}$ represent the first differenced model-free implied volatility for the S\&P 500 and WTI crude oil respectively. $\Delta S_{S P}$ and $\Delta S_{C}$ and $\Delta K_{S P}$ and $\Delta K_{C}$ represent, respectively, the ARMA(1,1) based innovations in implied skewness and kurtosis for the S\&P 500 and crude oil. Correlations above the diagonal are rank correlations. The superscript ${ }^{* * *}$ represents significance at $1 \%,{ }^{* *}$ represents significance at $5 \%$, and ${ }^{*}$ represents significance at $10 \%$.

\begin{tabular}{|c|c|c|c|c|c|c|c|c|c|}
\hline \multicolumn{10}{|c|}{ Panel A. Returns and Levels of High Moments } \\
\hline & & $R_{M}$ & $V_{S P}$ & $S_{S P}$ & $K_{S P}$ & $R_{C}$ & $V_{C}$ & $S_{C}$ & $K_{C}$ \\
\hline Nobs & & 4007 & 4008 & 4008 & 4008 & 4018 & 4018 & 4018 & 4018 \\
\hline Mean & & $3.4 \mathrm{E}-04$ & 0.223 & -1.561 & 7.929 & 4.0E-04 & 0.378 & -0.199 & 3.294 \\
\hline Std & & 0.013 & 0.087 & 0.543 & 3.886 & 0.024 & 0.113 & 0.216 & 0.605 \\
\hline Corr & $R_{M}$ & 1 & $-0.102^{* * *}$ & $-0.063^{* * *}$ & $0.084^{* * *}$ & $0.117^{* * *}$ & -0.018 & -0.018 & -0.007 \\
\hline Corr & $V_{S P}$ & $-0.129^{* * *}$ & 1 & $0.417^{* * *}$ & $-0.563^{* * *}$ & $-0.031^{* *}$ & $0.474^{* * *}$ & $-0.072^{* * *}$ & 0.002 \\
\hline Corr & $S_{S P}$ & $-0.058^{* * *}$ & $0.393^{* * *}$ & 1 & $-0.917^{* * *}$ & -0.018 & $0.255^{* * *}$ & $0.094^{* * *}$ & $-0.144^{* * *}$ \\
\hline Corr & $K_{S P}$ & $0.067^{* * *}$ & $-0.477^{* * *}$ & $-0.881^{* * *}$ & 1 & 0.018 & $-0.242^{* * *}$ & $-0.055^{* * *}$ & $0.113^{* * *}$ \\
\hline Corr & $R_{C}$ & $0.173^{* * *}$ & $-0.073^{* * *}$ & -0.021 & 0.019 & 1 & -0.019 & -0.014 & 0.016 \\
\hline Corr & $V_{C}$ & -0.021 & $0.670^{* * *}$ & $0.282^{* * *}$ & $-0.283^{* * *}$ & $-0.053^{* * *}$ & 1 & $0.169^{* * *}$ & $0.044^{* * *}$ \\
\hline Corr & $S_{C}$ & -0.014 & $-0.152^{* * *}$ & $0.061^{* * *}$ & $-0.031^{* *}$ & 0.000 & 0.015 & 1 & $-0.362^{* * *}$ \\
\hline Corr & $K_{C}$ & -0.010 & 0.022 & $-0.098^{* * *}$ & $0.087^{* * *}$ & 0.020 & $0.052^{* * *}$ & $-0.100^{* * *}$ & 1 \\
\hline \multicolumn{10}{|c|}{ Panel B. Returns and Innovations of High Moments } \\
\hline & & $R_{M}$ & $\Delta V_{S P}$ & $\Delta S_{S P}$ & $\Delta K_{S P}$ & $R_{C}$ & $\Delta V_{C}$ & $\Delta S_{C}$ & $\Delta K_{C}$ \\
\hline Nobs & & 4007 & 4008 & 4008 & 4008 & 4018 & 4017 & 4018 & 4018 \\
\hline Mean & & $3.4 \mathrm{E}-04$ & $2.6 \mathrm{E}-05$ & $8.4 \mathrm{E}-04$ & $-5.3 \mathrm{E}-03$ & 4.0E-04 & $4.2 \mathrm{E}-05$ & $5.1 \mathrm{E}-05$ & $1.5 \mathrm{E}-04$ \\
\hline Std & & 0.013 & 0.017 & 0.265 & 1.780 & 0.024 & 0.019 & 0.096 & 0.463 \\
\hline Corr & $R_{M}$ & 1 & $-0.779^{* * *}$ & $-0.194^{* * *}$ & $0.297^{* * *}$ & $0.117^{* * *}$ & $-0.130^{* * *}$ & -0.025 & -0.002 \\
\hline Corr & $\Delta V_{S P}$ & $-0.816^{* * *}$ & 1 & $0.154^{* * *}$ & $-0.274^{* * *}$ & $-0.098^{* * *}$ & $0.183^{* * *}$ & $0.028^{*}$ & -0.001 \\
\hline Corr & $\Delta S_{S P}$ & $-0.129^{* * *}$ & $0.101^{* * *}$ & 1 & -0.806 & -0.035 & 0.059 & 0.015 & -0.013 \\
\hline Corr & $\Delta K_{S P}$ & $0.149^{* * *}$ & $-0.131^{* * *}$ & $-0.658^{* * *}$ & 1 & $0.038^{* *}$ & $-0.080^{* * *}$ & -0.009 & 0.006 \\
\hline Corr & $R_{C}$ & $0.173^{* * *}$ & $-0.154^{* * *}$ & -0.022 & $0.030^{*}$ & 1 & $-0.114^{* * *}$ & -0.005 & $0.078^{* * *}$ \\
\hline Corr & $\Delta V_{C}$ & $-0.209^{* * *}$ & $0.270^{* * *}$ & $0.035^{* *}$ & $-0.048^{* * *}$ & $-0.189^{* * *}$ & 1 & 0.013 & $0.064^{* * *}$ \\
\hline Corr & $\Delta S_{C}$ & -0.008 & -0.002 & $0.039^{* *}$ & $-0.047^{* * *}$ & 0.013 & 0.000 & 1 & $-0.157^{* * *}$ \\
\hline Corr & $\Delta V_{C}$ & -0.006 & 0.007 & $-0.035^{* *}$ & $0.047^{* * *}$ & 0.025 & $0.096^{* * *}$ & $-0.436^{* * *}$ & 1 \\
\hline
\end{tabular}




\section{Table 3: PNG Stock Returns and Crude Moments - Pooled Regressions}

Panel A reports results from pooled cross-sectional regressions of the form

$$
E R_{i, t}=\alpha+\beta_{1} E R_{M, t}+\beta_{2} R_{C, t}+\beta_{3} \Delta V_{C, t}+\beta_{4} \Delta S_{C, t}+\beta_{5} \Delta K_{C, t}+\varepsilon_{t}
$$

Panel B reports average parameters from regressions that are run separately for each corporation using daily data over each calendar quarter. Statistics in [ ] are Newey-West t-statistics. The superscript ${ }^{* * *}$ represents significance at $1 \%,{ }^{* *}$ represents significance at $5 \%$, and ${ }^{*}$ represents significance at $10 \%$.

\begin{tabular}{|c|c|c|c|c|c|c|}
\hline Model & $\hat{\beta}_{1}$ & $\hat{\beta}_{2}$ & $\hat{\beta}_{3}$ & $\hat{\beta}_{4}$ & $\hat{\beta}_{5}$ & $\operatorname{AdjR}^{2}$ \\
\hline \multicolumn{7}{|c|}{ Panel A. Parameters from pooled time-series regressions } \\
\hline 1 & $\begin{array}{c}0.990^{* * *} \\
{[225.19]}\end{array}$ & & & & & 0.071 \\
\hline 2 & & $\begin{array}{c}0.369^{* * *} \\
{[148.05]}\end{array}$ & & & & 0.032 \\
\hline 3 & $\begin{array}{c}0.905^{* * *} \\
{[205.21]}\end{array}$ & $\begin{array}{c}0.287^{* * *} \\
{[116.91]}\end{array}$ & & & & 0.089 \\
\hline 4 & & & $\begin{array}{r}-0.240^{* * *} \\
{[-73.95]}\end{array}$ & $\begin{array}{r}0.005^{* * *} \\
{[6.87]}\end{array}$ & $\begin{array}{r}0.001^{* * *} \\
{[8.71]}\end{array}$ & 0.008 \\
\hline 5 & $\begin{array}{c}0.894^{* * *} \\
{[199.60]}\end{array}$ & $\begin{array}{c}0.281^{* * *} \\
{[113.26]}\end{array}$ & $\begin{array}{r}-0.046^{* * *} \\
{[-14.45]}\end{array}$ & $\begin{array}{r}0.005^{* * *} \\
{[7.87]}\end{array}$ & $\begin{array}{l}0.001 \\
{[1.04]}\end{array}$ & 0.090 \\
\hline \multicolumn{7}{|c|}{ Panel B. Averages of quarterly parameters from individual regressions } \\
\hline 1 & $\begin{array}{r}0.849^{* * *} \\
{[65.98]}\end{array}$ & & & & & 0.141 \\
\hline 2 & & $\begin{array}{r}0.331^{* * *} \\
{[52.41]}\end{array}$ & & & & 0.084 \\
\hline 3 & $\begin{array}{r}0.807^{* * *} \\
{[66.59]}\end{array}$ & $\begin{array}{r}0.240^{* * *} \\
{[48.07]}\end{array}$ & & & & 0.190 \\
\hline 4 & & & $\begin{array}{r}-0.169^{* * *} \\
{[-21.14]}\end{array}$ & $\begin{array}{r}-0.033^{* * *} \\
{[-10.23]}\end{array}$ & $\begin{array}{r}0.016^{* * *} \\
{[11.30]}\end{array}$ & 0.033 \\
\hline 5 & $\begin{array}{r}0.810^{* * *} \\
{[64.14]}\end{array}$ & $\begin{array}{r}0.236^{* * *} \\
{[43.49]}\end{array}$ & $\begin{array}{r}-0.020^{* * * *} \\
{[-2.88]}\end{array}$ & $\begin{array}{r}-0.011^{* * *} \\
{[-2.78]}\end{array}$ & $\begin{array}{r}0.008^{* * *} \\
{[4.44]}\end{array}$ & 0.193 \\
\hline
\end{tabular}




\section{Table 4: PNG Stock Returns and Crude Moments - Individual Regressions}

Coefficient estimates and Adjusted $\mathrm{R}^{2} \mathrm{~s}$ are averages from individual-company regressions over each calendar quarter. The regression is of the form:

$E R_{i, t}=\alpha+\beta_{1} E R_{M, t}+\beta_{2} \Delta V_{S P, t}+\beta_{3} \Delta S_{S P, t}+\beta_{4} \Delta K_{S P, t}+\beta_{5} R_{C, t}+\beta_{6} \Delta V_{C, t}+\beta_{7} \Delta S_{C, t}+\beta_{8} \Delta K_{C, t}+\varepsilon_{t}$.

The size classifications are based on the $20^{t h}$ and $50^{t h}$ percentile of market capitalization at the end of June of the prior year (see Fama and French (2008)). Statistics in [ ] are Newey-West t-statistics. The superscript ${ }^{* * *}$ represents significance at $1 \%,{ }^{* *}$ represents significance at $5 \%$, and ${ }^{*}$ represents significance at $10 \%$.

\begin{tabular}{|c|c|c|c|c|c|c|c|c|c|}
\hline Model & $\hat{\beta}_{1}$ & $\hat{\beta}_{2}$ & $\hat{\beta}_{3}$ & $\hat{\beta}_{4}$ & $\hat{\beta}_{5}$ & $\hat{\beta}_{6}$ & $\hat{\beta}_{7}$ & $\hat{\beta}_{8}$ & $\operatorname{Adj}^{2}$ \\
\hline \multicolumn{10}{|c|}{ A. All Firms } \\
\hline 1 & $\begin{array}{r}0.899^{* * *} \\
{[46.93]}\end{array}$ & $\begin{array}{r}0.065^{* * *} \\
{[4.59]}\end{array}$ & $\begin{array}{l}-0.001 \\
{[-0.86]}\end{array}$ & $\begin{array}{l}0.000 \\
{[0.09]}\end{array}$ & & & & & 0.145 \\
\hline 2 & & & & & $\begin{array}{r}0.306^{* * *} \\
{[51.26]}\end{array}$ & $\begin{array}{r}-0.079^{* * *} \\
{[-12.14]}\end{array}$ & $\begin{array}{r}0.003^{*} \\
{[1.84]}\end{array}$ & $\begin{array}{r}0.004^{* * *} \\
{[3.99]}\end{array}$ & 0.091 \\
\hline 3 & $\begin{array}{r}0.796^{* * *} \\
{[30.83]}\end{array}$ & $\begin{array}{l}0.030 \\
{[1.05]}\end{array}$ & $\begin{array}{l}0.002 \\
{[1.33]}\end{array}$ & $\begin{array}{r}0.001^{*} \\
{[1.73]}\end{array}$ & $\begin{array}{r}0.229^{* * *} \\
{[33.06]}\end{array}$ & $\begin{array}{r}0.000 \\
{[-0.04]}\end{array}$ & $\begin{array}{r}0.008^{* * *} \\
{[2.81]}\end{array}$ & $\begin{array}{r}0.006^{* * *} \\
{[5.47]}\end{array}$ & 0.196 \\
\hline
\end{tabular}

B. Big Cap Firms

$\begin{array}{rrrrrrrrrr}1 & 1.014^{* * *} & 0.015 & -0.000 & -0.001^{* *} & & & & & 0.243 \\ & {[46.52]} & {[1.45]} & {[-0.14]} & {[-2.49]} & & & & & \\ 2 & & & & & 0.397^{* * *} & -0.099^{* * *} & 0.001 & -0.002^{*} & 0.166 \\ & & & & & {[44.90]} & {[-17.05]} & {[0.52]} & {[-1.77]} & \\ 3 & 0.932^{* * *} & -0.003 & -0.001 & 0.000 & 0.302^{* * *} & -0.032^{* * *} & 0.003 & 0.002^{*} & 0.339 \\ & {[49.08]} & {[-.39]} & {[-1.29]} & {[-.20]} & {[41.15]} & {[-6.09]} & {[1.41]} & {[1.80]} & \end{array}$

C. Small Cap Firms

$\begin{array}{rrrrrrrrrr}1 & 1.181^{* * *} & 0.062^{* * *} & 0.001 & -0.001^{* *} & & & & & 0.180 \\ & {[39.96]} & {[4.25]} & {[0.62]} & {[-2.24]} & & & & & \\ 2 & & & & & 0.369^{* * *} & -0.086^{* * *} & -0.003 & 0.001 & 0.102 \\ & & & & & {[33.73]} & {[-7.81]} & {[-0.89]} & {[0.54]} & \\ 3 & 1.099^{* * *} & 0.035^{* *} & -0.001 & 0.000 & 0.281^{* * *} & -0.024^{* * *} & -0.004 & 0.003^{* *} & 0.239 \\ & {[40.26]} & {[2.36]} & {[-1.08]} & {[-.49]} & {[32.32]} & {[-3.59]} & {[-1.08]} & {[2.01]} & \end{array}$

D. Micro Cap Firms

\begin{tabular}{rrrrrrrrrr}
1 & $0.691^{* * *}$ & $0.097^{* * *}$ & 0.001 & 0.001 & & & & & 0.067 \\
& {$[20.32]$} & {$[3.44]$} & {$[.63]$} & {$[1.58]$} & & & & & \\
2 & & & & & $0.220^{* * *}$ & $-0.063^{* * *}$ & $-0.012^{* *}$ & $0.010^{* * *}$ & 0.039 \\
& & & & & {$[23.65]$} & {$[-5.30]$} & {$[-2.41]$} & {$[4.94]$} & \\
3 & $0.564^{* * *}$ & 0.048 & -0.008 & $0.003^{*}$ & $0.159^{* * *}$ & 0.030 & $-0.011^{*}$ & $0.010^{* * *}$ & 0.088 \\
& {$[11.22]$} & {$[0.81]$} & {$[-1.01]$} & {$[1.81]$} & {$[12.42]$} & {$[1.14]$} & {$[-1.78]$} & {$[4.81]$} & \\
\hline
\end{tabular}




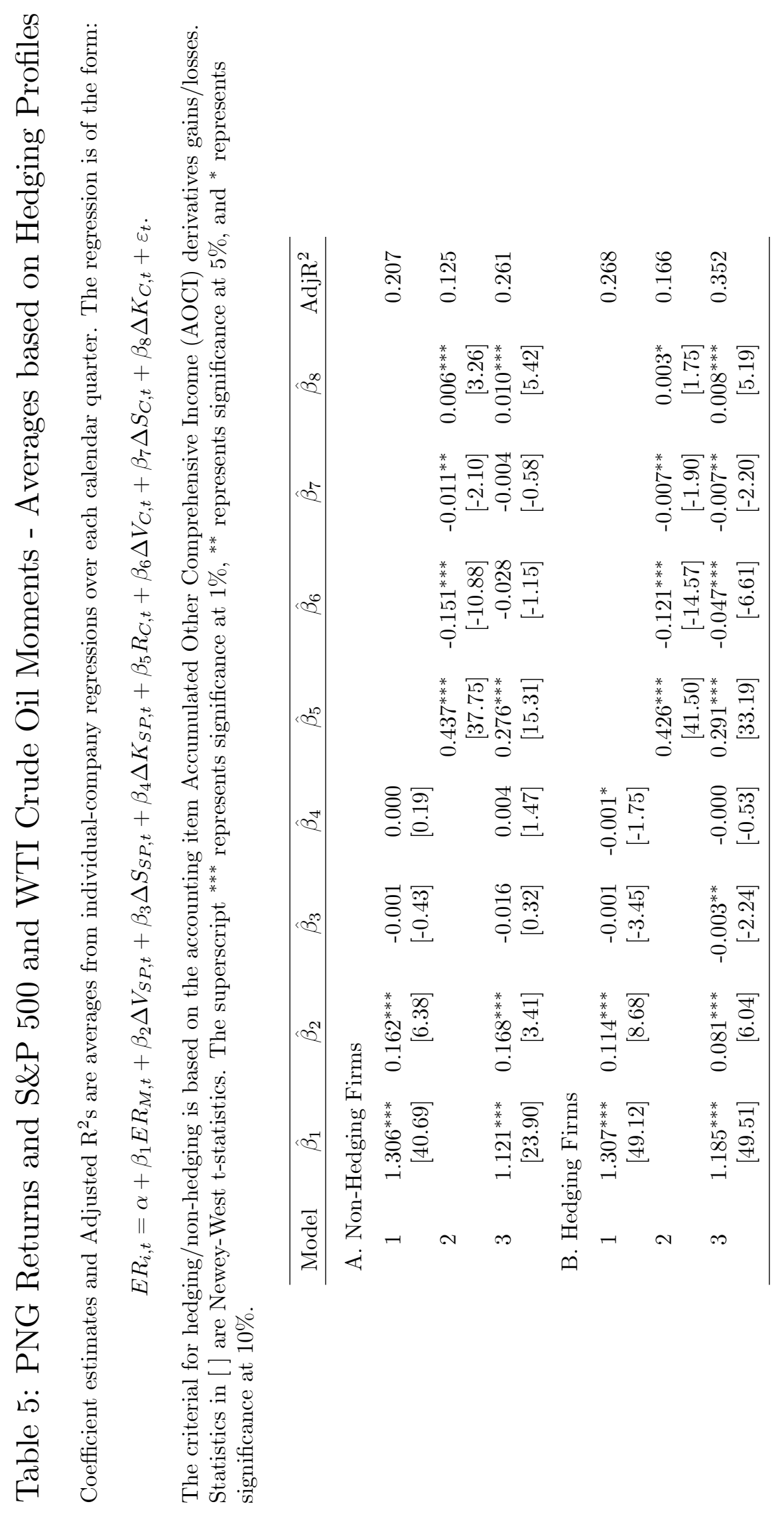




\section{Table 6: Performance of Portfolios Sorted by Volatility Loadings}

Monthly regressions for each stock in the sample are estimated to separately obtain the loadings on crude and S\&P 500 volatility innovations. The regression equations are ("univarite"):

$E R_{i, t}=\alpha+\beta_{1} E R_{M, t}+\beta_{2} R_{C, t}+\beta_{V}^{S P} \Delta V_{S P, t}+\varepsilon_{t}$, and $E R_{i, t}=\alpha+\beta_{1} E R_{M, t}+\beta_{2} R_{C, t}+\beta_{V}^{C} \Delta V_{C, t}+\varepsilon_{t}$, and ("multivariate"):

$E R_{i, t}=\alpha+\beta_{1} E R_{M, t}+\beta_{2} \Delta V_{S P, t}+\beta_{3} \Delta S_{S P, t}+\beta_{4} \Delta K_{S P, t}+\beta_{5} R_{C, t}+\beta_{6} \Delta V_{C, t}+\beta_{7} \Delta S_{C, t}+\beta_{8} \Delta K_{C, t}+\varepsilon_{t}$.

For every calendar month, we form value-weighted quitile portfolios based on the size of the loadings of either crude volatility or market volatility innovations. The volatility premia (or lack of it) is determined by the size of the Jesen's alphas respected to the Carhart's four factor model augmented by the return of crude oil futures in the subsequent month. This table reports the monthly alphas, and average returns. Statistics in [ ] are Newey-West t-statistics elsewhere and regular t-statistics for the $(5-1)$ portfolio. The superscript ${ }^{* * *},{ }^{* *}$, and ${ }^{*}$ represents significance at $1 \%, 5 \%$ and $10 \%$, respectively.

\begin{tabular}{|c|c|c|c|c|c|c|}
\hline \multirow[b]{2}{*}{ Sorting Statistic } & \multicolumn{6}{|c|}{ Quintile Porfolio } \\
\hline & 1 & 2 & 3 & 4 & 5 & $5-1$ \\
\hline \multicolumn{7}{|l|}{ Panel A: Crude Oil } \\
\hline \multicolumn{7}{|l|}{ Univariate Models } \\
\hline Volatility Beta & $\begin{array}{r}-1.052^{* * *} \\
{[-44.72]}\end{array}$ & $\begin{array}{r}-0.268^{* * *} \\
{[-44.50]}\end{array}$ & $\begin{array}{l}-0.004 \\
{[-0.77]}\end{array}$ & $\begin{array}{r}0.256^{* * *} \\
{[38.58]}\end{array}$ & $\begin{array}{r}1.066^{* * *} \\
{[45.78]}\end{array}$ & $\begin{array}{r}2.118^{* * *} \\
{[98.68]}\end{array}$ \\
\hline Average Return & $\begin{array}{r}1.801^{* *} \\
{[2.18]}\end{array}$ & $\begin{array}{r}1.491^{* *} \\
{[2.36]}\end{array}$ & $\begin{array}{r}1.616^{* * *} \\
{[2.79]}\end{array}$ & $\begin{array}{r}1.575^{* *} \\
{[2.56]}\end{array}$ & $\begin{array}{r}1.668^{* *} \\
{[1.97]}\end{array}$ & $\begin{array}{l}-0.134 \\
{[-0.11]}\end{array}$ \\
\hline Augmented Carhart alpha & $\begin{array}{l}0.199 \\
{[0.36]}\end{array}$ & $\begin{array}{l}-0.124 \\
{[-0.31]}\end{array}$ & $\begin{array}{l}-0.171 \\
{[-0.42]}\end{array}$ & $\begin{array}{l}-0.270 \\
{[-0.60]}\end{array}$ & $\begin{array}{l}-0.318 \\
{[-0.62]}\end{array}$ & $\begin{array}{l}-0.517 \\
{[-0.62]}\end{array}$ \\
\hline \multicolumn{7}{|l|}{ Multiivariate Models } \\
\hline Volatility Beta & $\begin{array}{r}-1.385^{* * *} \\
{[-16.83]}\end{array}$ & $\begin{array}{r}-0.322^{* * *} \\
{[-45.03]}\end{array}$ & $\begin{array}{l}0.004 \\
{[0.70]}\end{array}$ & $\begin{array}{r}0.337^{* * *} \\
{[41.87]}\end{array}$ & $\begin{array}{r}1.517^{* * *} \\
{[11.82]}\end{array}$ & $\begin{array}{r}2.902^{* * *} \\
{[19.68]}\end{array}$ \\
\hline Average Return & $\begin{array}{l}1.240 \\
{[1.53]}\end{array}$ & $\begin{array}{r}1.425^{* *} \\
{[2.18]}\end{array}$ & $\begin{array}{r}1.419^{* *} \\
{[2.50]}\end{array}$ & $\begin{array}{r}1.490^{* *} \\
{[2.40]}\end{array}$ & $\begin{array}{r}1.550^{*} \\
{[1.80]}\end{array}$ & $\begin{array}{l}0.309 \\
{[0.27]}\end{array}$ \\
\hline Augmented Carhart alpha & $\begin{array}{l}-0.553 \\
{[-1.05]}\end{array}$ & $\begin{array}{l}-0.302 \\
{[-0.67]}\end{array}$ & $\begin{array}{l}-0.309 \\
{[-0.83]}\end{array}$ & $\begin{array}{l}-0.253 \\
{[-0.58]}\end{array}$ & $\begin{array}{l}0.022 \\
{[0.04]}\end{array}$ & $\begin{array}{l}0.575 \\
{[0.70]}\end{array}$ \\
\hline \multicolumn{6}{|l|}{ Panel B: S\&P 500} & Univariate Models \\
\hline Volatility Beta & $\begin{array}{r}-1.854^{* * *} \\
{[-35.58]}\end{array}$ & $\begin{array}{r}-0.475^{* * *} \\
{[-42.54]}\end{array}$ & $\begin{array}{l}-0.005 \\
{[-0.47]}\end{array}$ & $\begin{array}{r}0.472^{* * *} \\
{[41.74]}\end{array}$ & $\begin{array}{r}1.914^{* * *} \\
{[50.15]}\end{array}$ & $\begin{array}{r}3.768^{* * *} \\
{[74.89]}\end{array}$ \\
\hline Average Return & $\begin{array}{r}1.476^{*} \\
{[1.90]}\end{array}$ & $\begin{array}{r}1.146^{*} \\
{[1.88]}\end{array}$ & $\begin{array}{r}1.070^{*} \\
{[1.80]}\end{array}$ & $\begin{array}{r}1.355^{* *} \\
{[2.04]}\end{array}$ & $\begin{array}{r}2.013^{* *} \\
{[2.39]}\end{array}$ & $\begin{array}{l}0.538 \\
{[0.47]}\end{array}$ \\
\hline Augmented Carhart alpha & $\begin{array}{l}0.134 \\
{[0.27]}\end{array}$ & $\begin{array}{r}-0.623^{*} \\
{[-1.75]}\end{array}$ & $\begin{array}{l}-0.473 \\
{[-1.10]}\end{array}$ & $\begin{array}{l}-0.262 \\
{[-0.63]}\end{array}$ & $\begin{array}{l}0.107 \\
{[0.19]}\end{array}$ & $\begin{array}{l}-0.027 \\
{[-0.03]}\end{array}$ \\
\hline \multicolumn{7}{|l|}{ Multivariate Models } \\
\hline Volatility Beta & $\begin{array}{r}-2.695^{* * *} \\
{[-12.83]}\end{array}$ & $\begin{array}{r}-0.568^{* * *} \\
{[-40.68]}\end{array}$ & $\begin{array}{l}0.015 \\
{[1.14]}\end{array}$ & $\begin{array}{r}0.605^{* * *} \\
{[39.60]}\end{array}$ & $\begin{array}{r}2.565^{* * *} \\
{[28.06]}\end{array}$ & $\begin{array}{r}5.260^{* * *} \\
{[23.90]}\end{array}$ \\
\hline Average Return & $\begin{array}{r}1.579^{* *} \\
{[2.13]}\end{array}$ & $\begin{array}{l}0.827 \\
{[1.33]}\end{array}$ & $\begin{array}{r}1.332^{* *} \\
{[2.29]}\end{array}$ & $\begin{array}{r}1.792^{* * *} \\
{[2.72]}\end{array}$ & $\begin{array}{r}2.366^{* * *} \\
{[2.86]}\end{array}$ & $\begin{array}{l}0.786 \\
{[0.70]}\end{array}$ \\
\hline Augmented Carhart alpha & $\begin{array}{l}-0.330 \\
{[-0.73]}\end{array}$ & $\begin{array}{l}-0.562 \\
{[-1.59]}\end{array}$ & $\begin{array}{l}-0.067 \\
{[-0.17]}\end{array}$ & $\begin{array}{l}-0.069 \\
{[-0.17]}\end{array}$ & $\begin{array}{l}0.325 \\
{[0.61]}\end{array}$ & $\begin{array}{l}0.655 \\
{[0.83]}\end{array}$ \\
\hline
\end{tabular}




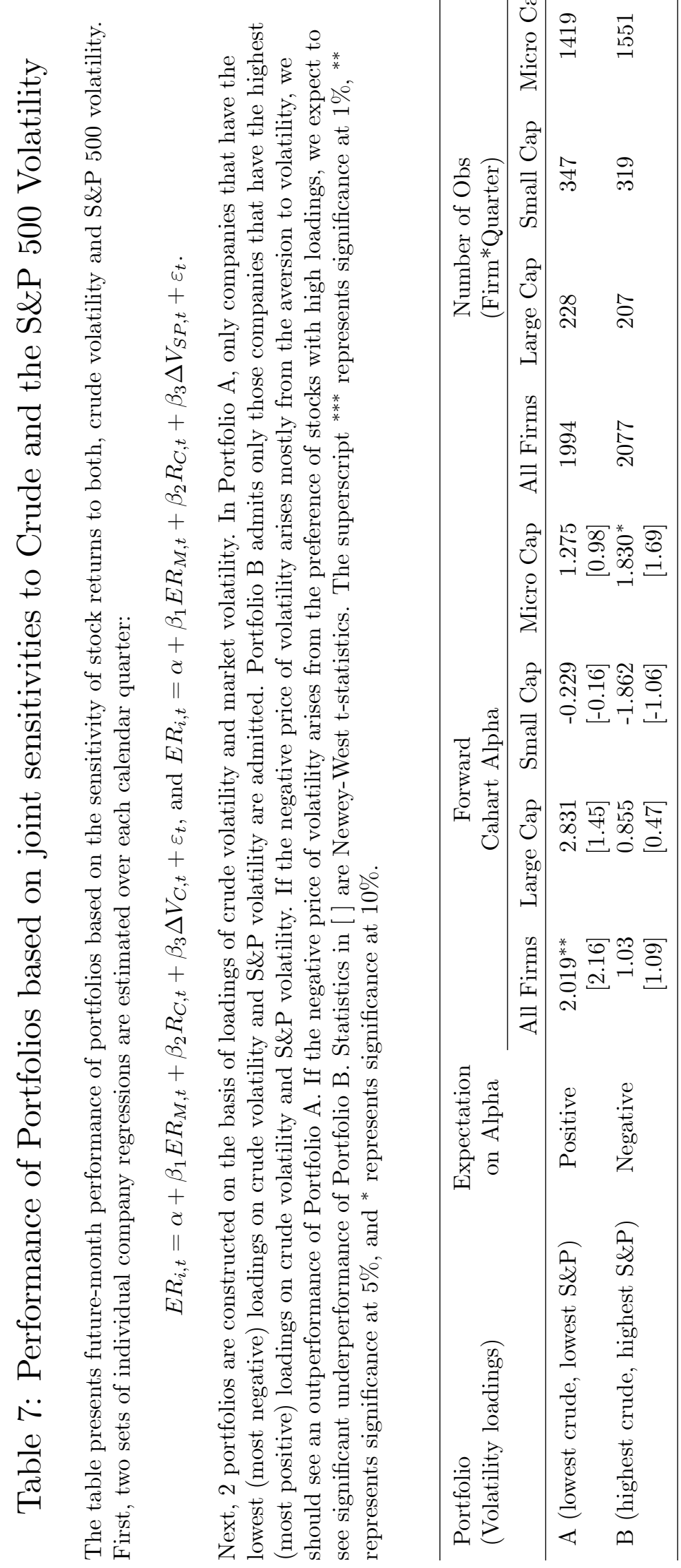




\section{Table 8: Performance of Portfolios Sorted by Skewness or Kurtosis Load- ings}

Monthly regressions for each stock in the sample are estimated to separately obtain the loadings on crude and S\&P 500 skewness innovations. The regression equations are:

$E R_{i, t}=\alpha+\beta_{1} E R_{M, t}+\beta_{2} R_{C, t}+\beta_{X}^{S P} \Delta X_{S P, t}+\varepsilon_{t}$, and $E R_{i, t}=\alpha+\beta_{1} E R_{M, t}+\beta_{2} R_{C, t}+\beta_{X}^{C} \Delta X_{C, t}+\varepsilon_{t}$,

where, $X$ referes to $S$ (for Skewness) or $K$ (for Kurtosis). For every calendar month, we form value-weighted quitile portfolios based on the size of the loadings of either crude or market skewness or kurtosis innovations. This table reports the monthly alphas, and average returns. Statistics in [ ] are Newey-West t-statistics elsewhere and regular t-statistics for the (5-1) portfolio. The superscript ${ }^{* * *}$, ** , and ${ }^{*}$ represents significance at $1 \%, 5 \%$ and $10 \%$, respectively. The superscript ${ }^{a}$, represents significance at $10 \%$ for a one tailed test.

\begin{tabular}{|c|c|c|c|c|c|c|}
\hline \multirow[b]{2}{*}{ Sorting Statistic } & \multicolumn{6}{|c|}{ Quintile Porfolio } \\
\hline & 1 & 2 & 3 & 4 & 5 & $5-1$ \\
\hline \multicolumn{7}{|l|}{ Panel A: Crude Oil Skewness } \\
\hline Skewness Beta (Univariate) & $\begin{array}{r}-0.303^{* * *} \\
{[-41.55]}\end{array}$ & $\begin{array}{r}-0.079^{* * *} \\
{[-35.05]}\end{array}$ & $\begin{array}{l}-0.002 \\
{[-1.35]}\end{array}$ & $\begin{array}{r}0.074^{* * *} \\
{[37.02]}\end{array}$ & $\begin{array}{r}0.305^{* * *} \\
{[37.43]}\end{array}$ & $\begin{array}{r}0.608^{* * *} \\
{[82.47]}\end{array}$ \\
\hline Average Return & $\begin{array}{l}1.024 \\
{[1.26]}\end{array}$ & $\begin{array}{r}1.584^{* *} \\
{[2.50]}\end{array}$ & $\begin{array}{r}1.568^{* * *} \\
{[2.68]}\end{array}$ & $\begin{array}{l}0.961 \\
{[1.52]}\end{array}$ & $\begin{array}{r}2.277^{* * * *} \\
{[2.75]}\end{array}$ & $\begin{array}{l}1.252 \\
{[1.08]}\end{array}$ \\
\hline Augmented Carhart alpha & $\begin{array}{r}-0.880^{*} \\
{[-1.86]}\end{array}$ & $\begin{array}{l}-0.403 \\
{[-1.08]}\end{array}$ & $\begin{array}{l}0.134 \\
{[0.32]}\end{array}$ & $\begin{array}{l}-0.676 \\
{[-1.45]}\end{array}$ & $\begin{array}{l}0.289 \\
{[0.48]}\end{array}$ & $\begin{array}{r}1.169^{a} \\
{[1.53]}\end{array}$ \\
\hline \multicolumn{7}{|l|}{ Panel B: S\&P 500 Skewness } \\
\hline Skewness Beta (Univariate) & $\begin{array}{r}-0.089^{* * *} \\
{[-42.86]}\end{array}$ & $\begin{array}{r}-0.022^{* * *} \\
{[-41.67]}\end{array}$ & $\begin{array}{r}0.000 \\
{[-0.76]}\end{array}$ & $\begin{array}{r}0.021^{* * *} \\
{[39.88]}\end{array}$ & $\begin{array}{r}0.090^{* * *} \\
{[30.15]}\end{array}$ & $\begin{array}{r}0.179^{* * *} \\
{[63.28]}\end{array}$ \\
\hline Average Return & $\begin{array}{r}1.558^{*} \\
{[1.91]}\end{array}$ & $\begin{array}{r}1.494^{* *} \\
{[2.29]}\end{array}$ & $\begin{array}{r}1.424^{* *} \\
{[2.48]}\end{array}$ & $\begin{array}{r}1.290^{* *} \\
{[2.01]}\end{array}$ & $\begin{array}{r}2.082^{* * * *} \\
{[2.59]}\end{array}$ & $\begin{array}{l}0.524 \\
{[0.46]}\end{array}$ \\
\hline Augmented Carhart alpha & $\begin{array}{l}-0.074 \\
{[-0.15]}\end{array}$ & $\begin{array}{l}0.123 \\
{[0.27]}\end{array}$ & $\begin{array}{l}-0.283 \\
{[-0.77]}\end{array}$ & $\begin{array}{l}-0.460 \\
{[-1.09]}\end{array}$ & $\begin{array}{l}0.298 \\
{[0.62]}\end{array}$ & $\begin{array}{l}0.372 \\
{[0.47]}\end{array}$ \\
\hline \multicolumn{7}{|l|}{ Panel C: Crude Oil Kurtosis } \\
\hline Kurtosis Beta (Univariate) & $\begin{array}{r}-0.200^{* * *} \\
{[-41.83]}\end{array}$ & $\begin{array}{r}-0.049^{* * *} \\
{[-37.69]}\end{array}$ & $\begin{array}{l}0.002 \\
{[1.61]}\end{array}$ & $\begin{array}{r}0.054^{* * *} \\
{[38.90]}\end{array}$ & $\begin{array}{r}0.213^{* * *} \\
{[41.18]}\end{array}$ & $\begin{array}{r}0.413^{* * *} \\
{[94.26]}\end{array}$ \\
\hline Average Return & $\begin{array}{l}1.141 \\
{[1.35]}\end{array}$ & $\begin{array}{r}1.387^{* *} \\
{[2.29]}\end{array}$ & $\begin{array}{r}1.234^{* *} \\
{[2.07]}\end{array}$ & $\begin{array}{r}1.570^{* *} \\
{[2.37]}\end{array}$ & $\begin{array}{r}1.723^{* *} \\
{[2.11]}\end{array}$ & $\begin{array}{l}0.582 \\
{[0.50]}\end{array}$ \\
\hline Augmented Carhart alpha & $\begin{array}{l}-0.314 \\
{[-0.62]}\end{array}$ & $\begin{array}{l}-0.569 \\
{[-1.23]}\end{array}$ & $\begin{array}{l}-0.207 \\
{[-0.54]}\end{array}$ & $\begin{array}{l}-0.230 \\
{[-0.60]}\end{array}$ & $\begin{array}{l}-0.122 \\
{[-0.23]}\end{array}$ & $\begin{array}{l}0.192 \\
{[0.24]}\end{array}$ \\
\hline Panel D: S\&P 500 Kurtosis & & & & & & \\
\hline Kurtosis Beta (Univariate) & $\begin{array}{r}-0.023^{* * *} \\
{[-32.39]}\end{array}$ & $\begin{array}{r}-0.006^{* * *} \\
{[-31.22]}\end{array}$ & $\begin{array}{l}0.000 \\
{[1.35]}\end{array}$ & $\begin{array}{r}0.006^{* * *} \\
{[32.26]}\end{array}$ & $\begin{array}{r}0.025^{* * *} \\
{[26.58]}\end{array}$ & $\begin{array}{r}0.049^{* * *} \\
{[57.58]}\end{array}$ \\
\hline Average Return & $\begin{array}{r}1.801^{* *} \\
{[2.19]}\end{array}$ & $\begin{array}{r}1.301^{* *} \\
{[2.00]}\end{array}$ & $\begin{array}{r}1.295^{* *} \\
{[2.21]}\end{array}$ & $\begin{array}{r}1.319^{* *} \\
{[2.20]}\end{array}$ & $\begin{array}{r}2.040^{* *} \\
{[2.34]}\end{array}$ & $\begin{array}{l}0.239 \\
{[0.21]}\end{array}$ \\
\hline Augmented Carhart alpha & $\begin{array}{l}0.033 \\
{[0.06]}\end{array}$ & $\begin{array}{r}-0.815^{* *} \\
{[-2.00]}\end{array}$ & $\begin{array}{l}0.117 \\
{[0.29]}\end{array}$ & $\begin{array}{l}-0.062 \\
{[-0.16]}\end{array}$ & $\begin{array}{l}0.205 \\
{[0.34]}\end{array}$ & $\begin{array}{l}0.172 \\
{[0.20]}\end{array}$ \\
\hline
\end{tabular}


Figure 1: Daily Levels of S\&P 500 Moments
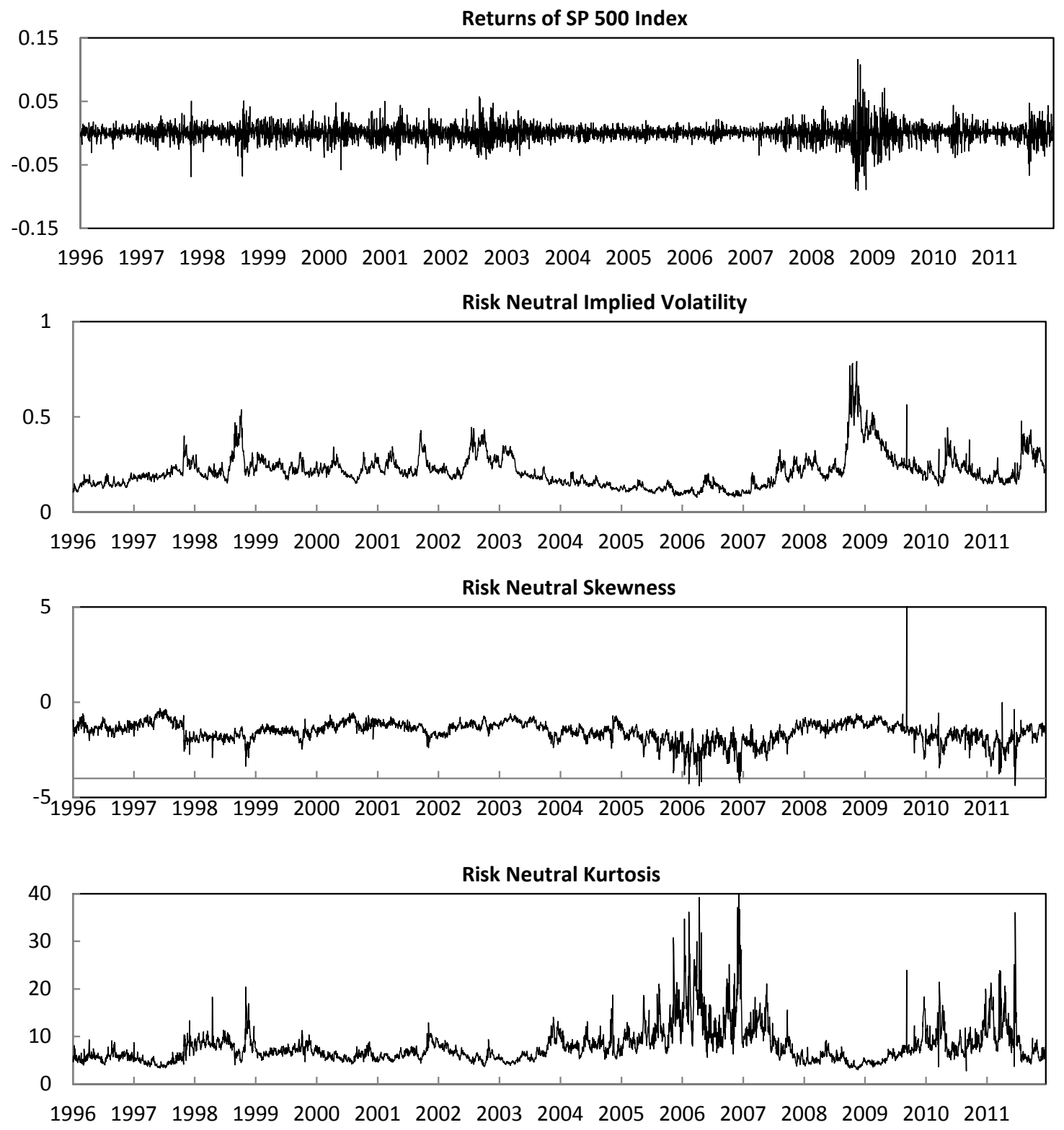
Figure 2: Daily Levels of WTI Crude Moments
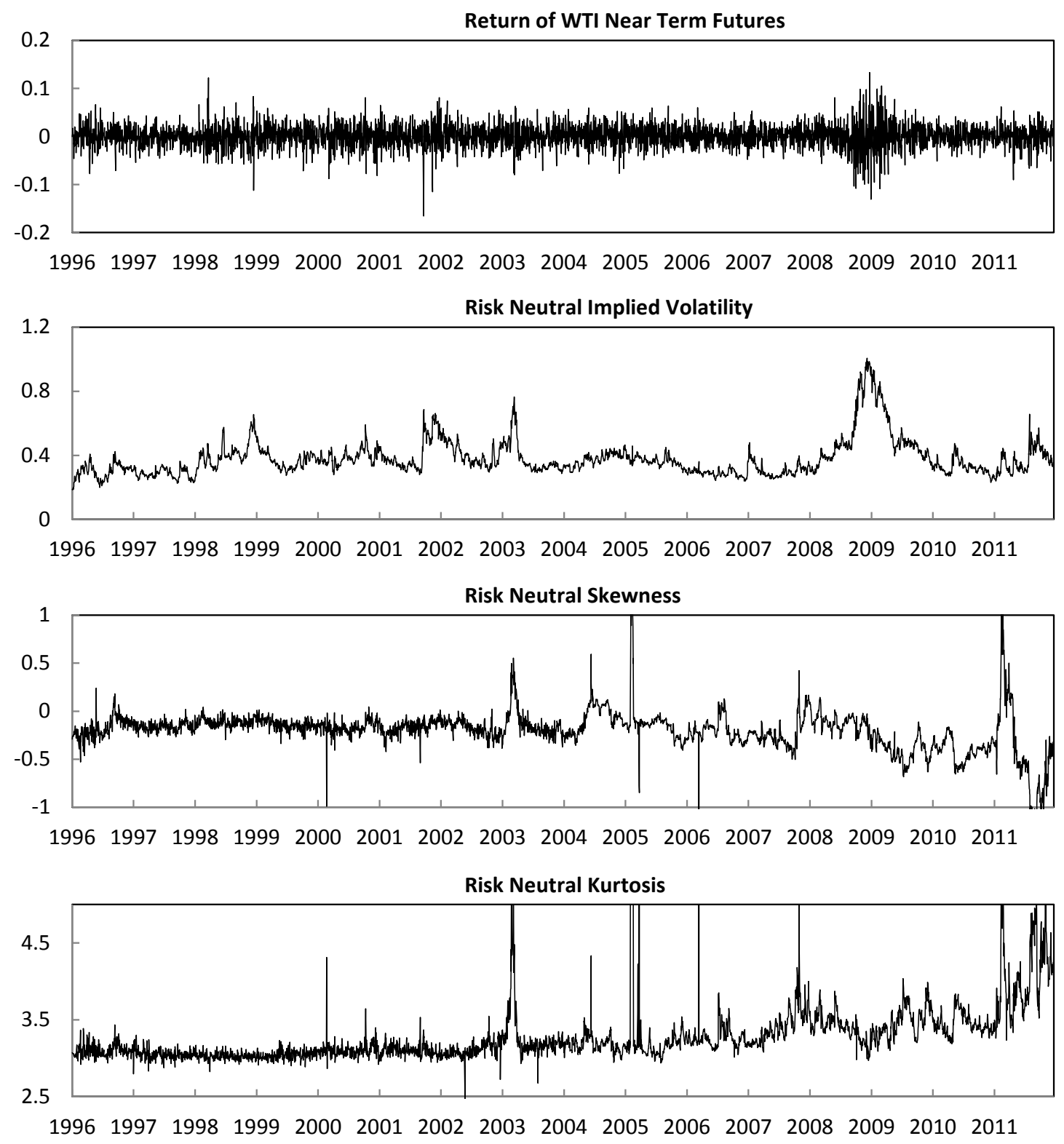
Figure 3: Autocorrelation Functions for WTI Crude Moments

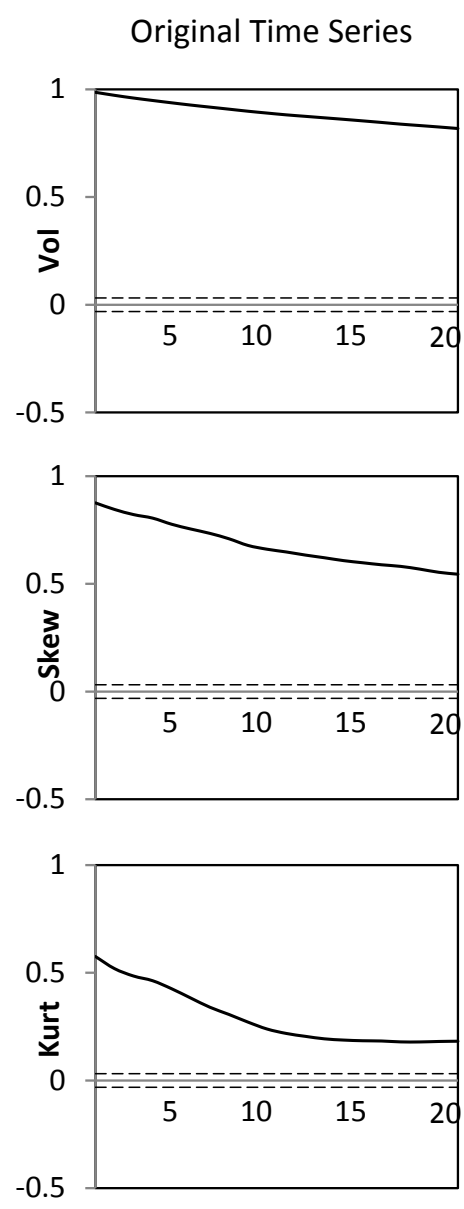

Lag Order
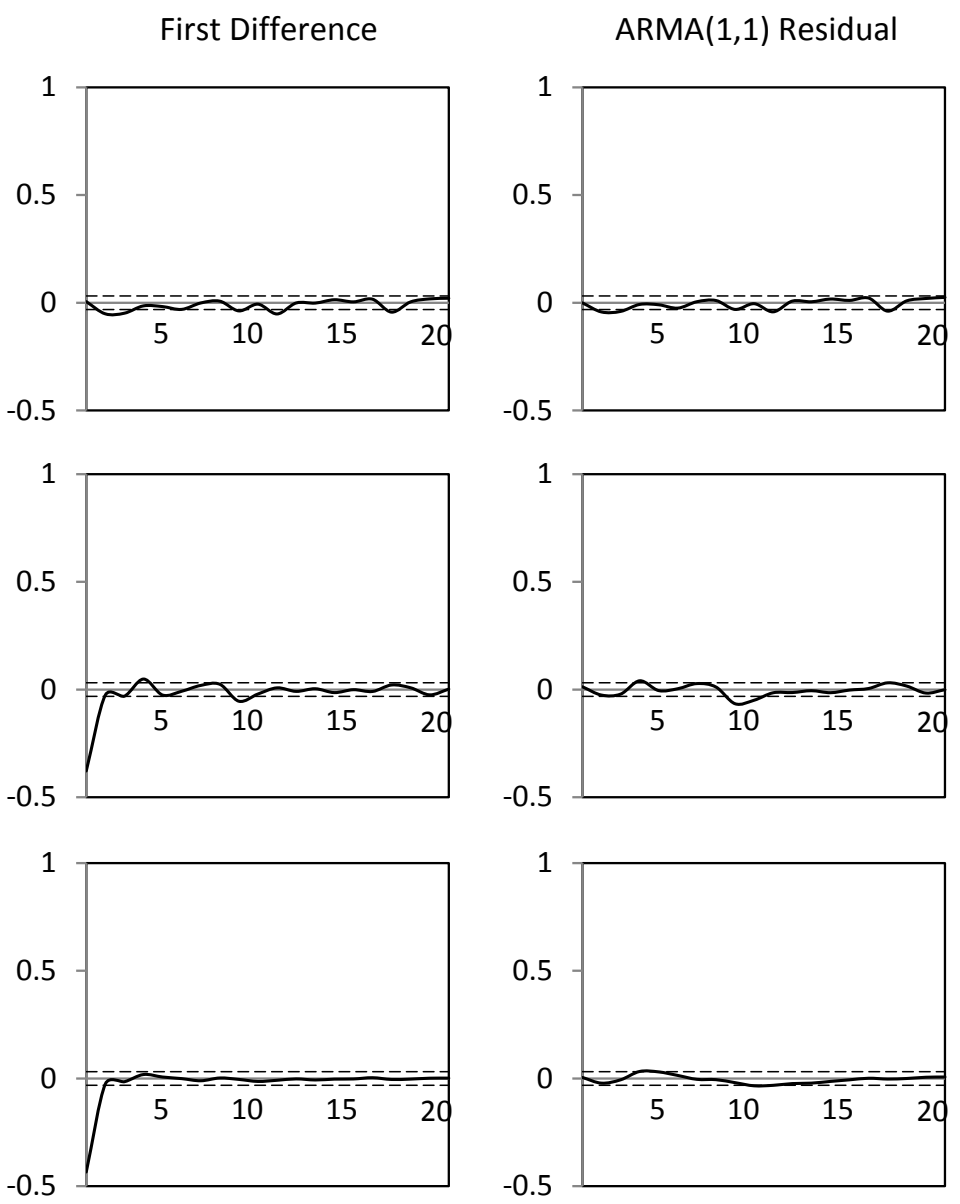

Lag Order

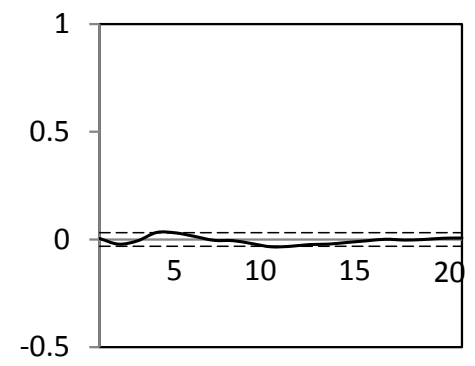

Lag Order 


\section{Figure 4: Time Variation in PNG Stock Return Sensitivities to Moment Innovations}

a.The sensitivities to $\mathrm{S} \& \mathrm{P}$ and crude volatility: The sensitivity to market (crude) volatility is mostly positive (negative). The innovations in the functions appear positively related, though the correlation is only 0.06. The scatterplot shows some extreme values in south-east quadrant (mostly from 2006-2008) that weaken an otherwise positive relationship. b. Sensitivities to S\&P and crude skewness: The correlation between the two functions is substantial at 0.228 . The extreme observation in the lower right-hand quadrant of the scatterplot is for Q3/2008. c. Sensitivities to S\&P and crude kurtosis: The functions are not correlated (correlation of 0.001 ). The scatterplot fails to indicate any systematic patterns

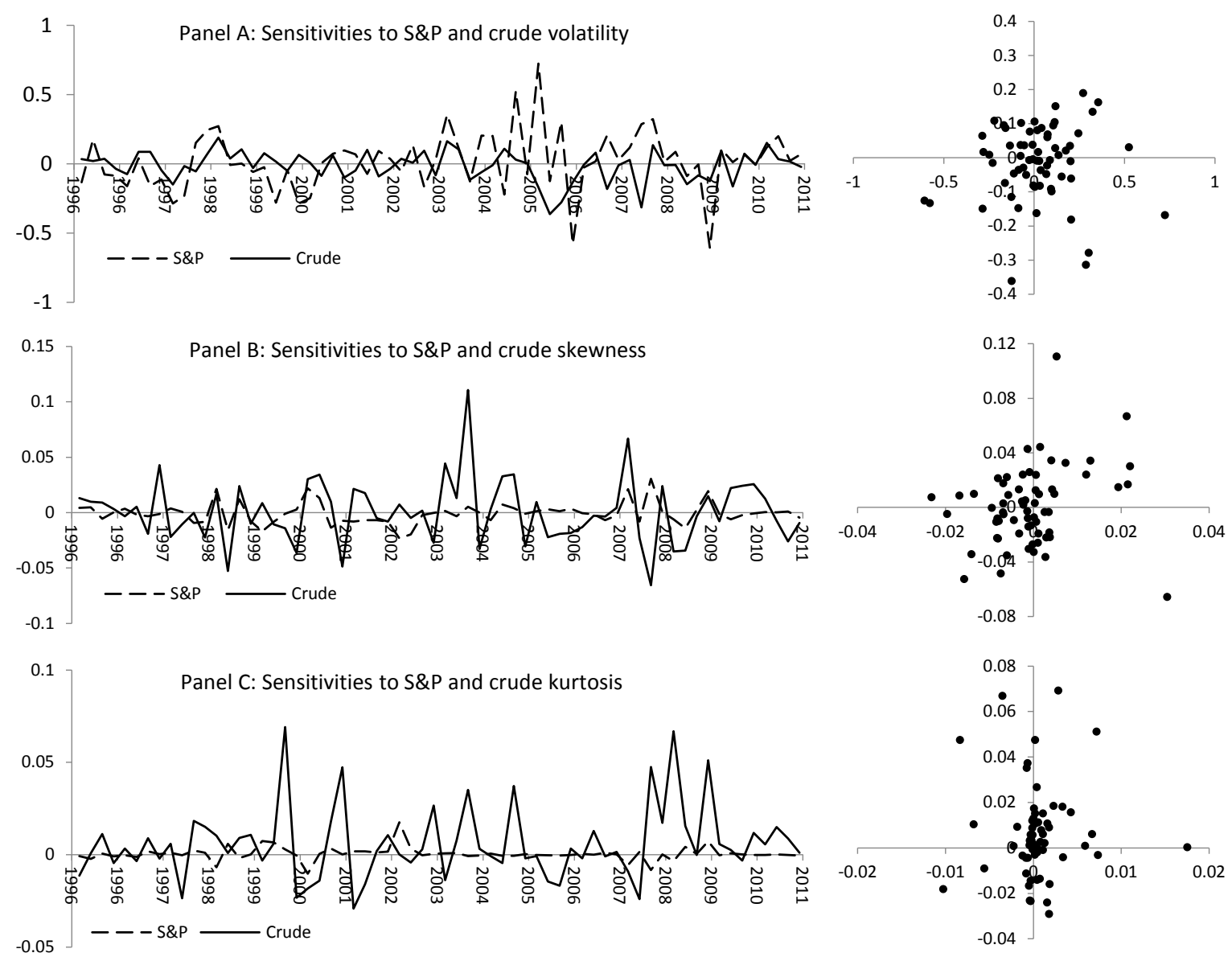




\section{Appendix: Supplementary Tables for the Reviewers}

\section{Table A1: Portfolios Sorted by Volatility Loadings: 1996-2006}

Monthly regressions for each stock in the sample are estimated to separately obtain the loadings on crude and S\&P 500 volatility innovations. The regression equations are (univarite):

$E R_{i, t}=\alpha+\beta_{1} E R_{M, t}+\beta_{2} R_{C, t}+\beta_{V}^{S P} \Delta V_{S P, t}+\varepsilon_{t}$, and $E R_{i, t}=\alpha+\beta_{1} E R_{M, t}+\beta_{2} R_{C, t}+\beta_{V}^{C} \Delta C_{C, t}+\varepsilon_{t}$, and (multivariate):

$E R_{i, t}=\alpha+\beta_{1} E R_{M, t}+\beta_{2} \Delta V_{S P, t}+\beta_{3} \Delta S_{S P, t}+\beta_{4} \Delta K_{S P, t}+\beta_{5} R_{C, t}+\beta_{6} \Delta V_{C, t}+\beta_{7} \Delta S_{C, t}+\beta_{8} \Delta K_{C, t}+\varepsilon_{t}$.

For every calendar month, we form value-weighted quitile portfolios based on the size of the loadings of either crude volatility or market volatility innovations. The volatility premia (or lack of it) is determined by the size of the Jesen's alphas respected to the Carhart's four factor model augmented by the return of crude oil futures in the subsequent month. This table reports the monthly alphas, and average returns. Statistics in [ ] are Newey-West t-statistics elsewhere and regular t-statistics for the (5-1) portfolio. The superscript ${ }^{* * *},{ }^{* *}$, and ${ }^{*}$ represents significance at $1 \%, 5 \%$ and $10 \%$, respectively.

\begin{tabular}{|c|c|c|c|c|c|c|}
\hline \multirow[b]{2}{*}{ Sorting Statistic } & \multicolumn{6}{|c|}{ Quintile Porfolio } \\
\hline & 1 & 2 & 3 & 4 & 5 & $5-1$ \\
\hline \multicolumn{7}{|l|}{ Panel A: Crude Oil } \\
\hline Volatility Beta (Univariate) & $\begin{array}{r}-1.106^{* * *} \\
{[-40.37]}\end{array}$ & $\begin{array}{r}-0.283^{* * *} \\
{[-36.79]}\end{array}$ & $\begin{array}{l}-0.004 \\
{[-0.66]}\end{array}$ & $\begin{array}{r}0.269^{* * *} \\
{[31.33]}\end{array}$ & $\begin{array}{r}1.157^{* * *} \\
{[38.47]}\end{array}$ & $\begin{array}{r}2.264^{* * *} \\
{[89.09]}\end{array}$ \\
\hline Average Return & $\begin{array}{r}1.994^{* *} \\
{[2.34]}\end{array}$ & $\begin{array}{r}1.795^{* * *} \\
{[2.75]}\end{array}$ & $\begin{array}{r}1.542^{* *} \\
{[2.44]}\end{array}$ & $\begin{array}{r}1.524^{* *} \\
{[2.33]}\end{array}$ & $\begin{array}{r}1.812^{* *} \\
{[1.97]}\end{array}$ & $\begin{array}{l}-0.183 \\
{[-0.15]}\end{array}$ \\
\hline Augument Carhart alpha & $\begin{array}{l}0.076 \\
{[0.11]}\end{array}$ & $\begin{array}{l}-0.255 \\
{[-0.51]}\end{array}$ & $\begin{array}{l}-0.502 \\
{[-1.00]}\end{array}$ & $\begin{array}{l}-0.731 \\
{[-1.29]}\end{array}$ & $\begin{array}{l}0.078 \\
{[0.11]}\end{array}$ & $\begin{array}{l}0.002 \\
{[0.00]}\end{array}$ \\
\hline Volatility Beta (Multivariate) & $\begin{array}{r}-1.450^{* * *} \\
{[-12.67]}\end{array}$ & $\begin{array}{r}-0.316^{* * *} \\
{[-35.15]}\end{array}$ & $\begin{array}{r}0.019^{* *} \\
{[2.45]}\end{array}$ & $\begin{array}{r}0.363^{* * *} \\
{[35.28]}\end{array}$ & $\begin{array}{r}1.671^{* * *} \\
{[9.30]}\end{array}$ & $\begin{array}{r}3.121^{* * *} \\
{[15.08]}\end{array}$ \\
\hline Average Return & $\begin{array}{r}1.646^{* *} \\
{[2.10]}\end{array}$ & $\begin{array}{r}1.669^{* *} \\
{[2.50]}\end{array}$ & $\begin{array}{r}1.611^{* * *} \\
{[2.62]}\end{array}$ & $\begin{array}{r}1.426^{* *} \\
{[2.16]}\end{array}$ & $\begin{array}{l}1.563 \\
{[1.59]}\end{array}$ & $\begin{array}{l}-0.083 \\
{[-0.07]}\end{array}$ \\
\hline Augument Carhart alpha & $\begin{array}{l}-0.507 \\
{[-0.75]}\end{array}$ & $\begin{array}{l}-0.575 \\
{[-1.12]}\end{array}$ & $\begin{array}{l}-0.468 \\
{[-1.11]}\end{array}$ & $\begin{array}{l}-0.620 \\
{[-1.08]}\end{array}$ & $\begin{array}{l}0.253 \\
{[0.36]}\end{array}$ & $\begin{array}{l}0.760 \\
{[0.73]}\end{array}$ \\
\hline \multicolumn{7}{|l|}{ Panel B: S\&P 500} \\
\hline Volatility Beta (Univariate) & $\begin{array}{r}-2.039^{* * *} \\
{[-46.22]}\end{array}$ & $\begin{array}{r}-0.545^{* * *} \\
{[-39.21]}\end{array}$ & $\begin{array}{r}-0.029^{* *} \\
{[-2.43]}\end{array}$ & $\begin{array}{r}0.486^{* * *} \\
{[34.98]}\end{array}$ & $\begin{array}{r}2.072^{* * *} \\
{[44.22]}\end{array}$ & $\begin{array}{c}4.111^{* * *} \\
{[101.35]}\end{array}$ \\
\hline Average Return & $\begin{array}{r}1.567^{*} \\
{[1.79]}\end{array}$ & $\begin{array}{r}1.225^{*} \\
{[1.90]}\end{array}$ & $\begin{array}{r}1.059^{*} \\
{[1.75]}\end{array}$ & $\begin{array}{r}1.716^{* *} \\
{[2.54]}\end{array}$ & $\begin{array}{r}1.969^{* *} \\
{[2.25]}\end{array}$ & $\begin{array}{l}0.401 \\
{[0.34]}\end{array}$ \\
\hline Augument Carhart alpha & $\begin{array}{l}0.226 \\
{[0.36]}\end{array}$ & $\begin{array}{r}-0.895^{*} \\
{[-1.97]}\end{array}$ & $\begin{array}{r}-0.891^{*} \\
{[-1.71]}\end{array}$ & $\begin{array}{l}-0.424 \\
{[-0.84]}\end{array}$ & $\begin{array}{l}-0.021 \\
{[-0.03]}\end{array}$ & $\begin{array}{l}-0.247 \\
{[-0.25]}\end{array}$ \\
\hline Volatility Beta (Multivariate) & $\begin{array}{r}-3.053^{* * *} \\
{[-10.47]}\end{array}$ & $\begin{array}{r}-0.633^{* * *} \\
{[-35.92]}\end{array}$ & $\begin{array}{l}-0.009 \\
{[-0.55]}\end{array}$ & $\begin{array}{r}0.626^{* * *} \\
{[33.48]}\end{array}$ & $\begin{array}{r}2.717^{* * *} \\
{[30.37]}\end{array}$ & $\begin{array}{r}5.770^{* * *} \\
{[19.61]}\end{array}$ \\
\hline Average Return & $\begin{array}{l}1.143 \\
{[1.42]}\end{array}$ & $\begin{array}{r}1.086^{*} \\
{[1.67]}\end{array}$ & $\begin{array}{r}1.462^{* *} \\
{[2.44]}\end{array}$ & $\begin{array}{r}2.082^{* * *} \\
{[3.15]}\end{array}$ & $\begin{array}{r}2.500^{* * *} \\
{[2.82]}\end{array}$ & $\begin{array}{l}1.357 \\
{[1.18]}\end{array}$ \\
\hline Augument Carhart alpha & $\begin{array}{l}-0.841 \\
{[-1.47]}\end{array}$ & $\begin{array}{r}-0.780^{*} \\
{[-1.71]}\end{array}$ & $\begin{array}{l}-0.413 \\
{[-0.87]}\end{array}$ & $\begin{array}{l}-0.298 \\
{[-0.64]}\end{array}$ & $\begin{array}{l}0.434 \\
{[0.65]}\end{array}$ & $\begin{array}{l}1.276 \\
{[1.28]}\end{array}$ \\
\hline
\end{tabular}




\section{Table A2: Portfolios Sorted by Volatility Loadings: 2007-2011}

Monthly regressions for each stock in the sample are estimated to separately obtain the loadings on crude and S\&P 500 volatility innovations. The regression equations are (univarite):

$E R_{i, t}=\alpha+\beta_{1} E R_{M, t}+\beta_{2} R_{C, t}+\beta_{V}^{S P} \Delta V_{S P, t}+\varepsilon_{t}$, and $E R_{i, t}=\alpha+\beta_{1} E R_{M, t}+\beta_{2} R_{C, t}+\beta_{V}^{C} \Delta C_{C, t}+\varepsilon_{t}$

and (multivariate):

$E R_{i, t}=\alpha+\beta_{1} E R_{M, t}+\beta_{2} \Delta V_{S P, t}+\beta_{3} \Delta S_{S P, t}+\beta_{4} \Delta K_{S P, t}+\beta_{5} R_{C, t}+\beta_{6} \Delta V_{C, t}+\beta_{7} \Delta S_{C, t}+\beta_{8} \Delta K_{C, t}+\varepsilon_{t}$.

For every calendar month, we form value-weighted quitile portfolios based on the size of the loadings of either crude volatility or market volatility innovations. The volatility premia (or lack of it) is

determined by the size of the Jesen's alphas respected to the Carhart's four factor model augmented by the return of crude oil futures in the subsequent month. This table reports the monthly alphas, and average returns. Statistics in [ ] are Newey-West t-statistics elsewhere and regular t-statistics for the (5-1) portfolio. The superscript ${ }^{* * *},{ }^{* *}$, and ${ }^{*}$ represents significance at $1 \%, 5 \%$ and $10 \%$, respectively.

\begin{tabular}{lrrrrrr}
\hline & \multicolumn{5}{c}{ Quintile Porfolio } \\
\cline { 2 - 7 } Sorting Statistic & \multicolumn{1}{c}{1} & \multicolumn{1}{c}{2} & \multicolumn{1}{c}{ } & \multicolumn{1}{c}{ } & \multicolumn{1}{c}{$5-1$} \\
\hline Panel A: Crude Oil & & & & & & \\
Volatility Beta (Univariate) & $-0.918^{* * *}$ & $-0.231^{* * *}$ & -0.003 & $0.225^{* * *}$ & $0.846^{* * *}$ & $1.764^{* * *}$ \\
& {$[-20.47]$} & {$[-26.99]$} & {$[-0.41]$} & {$[25.05]$} & {$[28.23]$} & {$[44.72]$} \\
Average Return & 1.420 & 0.820 & 1.721 & 1.707 & 1.436 & 0.016 \\
& {$[0.76]$} & {$[0.57]$} & {$[1.39]$} & {$[1.26]$} & {$[0.79]$} & {$[0.01]$} \\
Augument Carhart alpha & 0.472 & 0.134 & 0.444 & 0.724 & $-1.176^{* *}$ & -1.648 \\
& {$[0.53]$} & {$[0.19]$} & {$[0.65]$} & {$[1.08]$} & {$[-2.03]$} & {$[-1.25]$} \\
Volatility Beta (Multivariate) & $-1.228^{* * *}$ & $-0.338^{* * *}$ & $-0.032^{* * *}$ & $0.275^{* * *}$ & $1.144^{* * *}$ & $2.372^{* * *}$ \\
& {$[-25.36]$} & {$[-30.18]$} & {$[-3.34]$} & {$[24.35]$} & {$[18.76]$} & {$[38.17]$} \\
Average Return & 0.366 & 0.844 & 1.017 & 1.674 & 1.59 & 1.224 \\
& {$[0.19]$} & {$[0.56]$} & {$[0.84]$} & {$[1.23]$} & {$[0.91]$} & {$[0.46]$} \\
Augument Carhart alpha & -0.690 & 0.214 & 0.023 & 0.542 & -0.474 & 0.215 \\
& {$[-0.84]$} & {$[0.23]$} & {$[0.03]$} & {$[0.96]$} & {$[-0.69]$} & {$[0.16]$} \\
Panel B: S\&P 500 & & & & & & \\
Volatility Beta (Univariate) & $-1.405^{* * *}$ & $-0.304^{* * *}$ & $0.055^{* * *}$ & $0.440^{* * *}$ & $1.534^{* * *}$ & $2.940^{* * *}$ \\
& {$[-9.99]$} & {$[-19.92]$} & {$[3.59]$} & {$[23.00]$} & {$[25.09]$} & {$[20.91]$} \\
Average Return & 1.315 & 0.957 & 1.138 & 0.669 & 2.107 & 0.792 \\
& {$[0.83]$} & {$[0.71]$} & {$[0.83]$} & {$[0.44]$} & {$[1.10]$} & {$[0.30]$} \\
Augument Carhart alpha & -0.096 & -0.073 & 0.453 & 0.131 & 0.332 & 0.427 \\
Volatility Beta (Multivariate) & $-1.828^{* * *}$ & $-0.412^{* * *}$ & $0.072^{* * *}$ & $0.555^{* * *}$ & $2.196^{* * *}$ & $4.024^{* * *}$ \\
& {$[-14.71]$} & {$[-20.91]$} & {$[3.46]$} & {$[21.32]$} & {$[9.79]$} & {$[16.70]$} \\
Average Return & 2.565 & 0.256 & 1.098 & 1.239 & 2.146 & -0.419 \\
& {$[1.62]$} & {$[0.18]$} & {$[0.83]$} & {$[0.81]$} & {$[1.19]$} & {$[-0.16]$} \\
Augument Carhart alpha & 0.756 & -0.118 & 0.712 & 0.449 & 0.119 & -0.637 \\
& {$[1.21]$} & {$[-0.22]$} & {$[0.99]$} & {$[0.54]$} & {$[0.13]$} & {$[-0.50]$} \\
\hline
\end{tabular}




\section{Table A3: Portfolios Sorted by Skewness Loadings: 1996-2006}

Monthly regressions for each stock in the sample are estimated to separately obtain the loadings on crude and S\&P 500 skewness innovations. The regression equations are (univariate):

$E R_{i, t}=\alpha+\beta_{1} E R_{M, t}+\beta_{2} R_{C, t}+\beta_{S}^{S P} \Delta S_{S P, t}+\varepsilon_{t}$, and $E R_{i, t}=\alpha+\beta_{1} E R_{M, t}+\beta_{2} R_{C, t}+\beta_{S}^{C} \Delta S_{C, t}+\varepsilon_{t}$

and (multivariate):

$E R_{i, t}=\alpha+\beta_{1} E R_{M, t}+\beta_{2} \Delta V_{S P, t}+\beta_{3} \Delta S_{S P, t}+\beta_{4} \Delta K_{S P, t}+\beta_{5} R_{C, t}+\beta_{6} \Delta V_{C, t}+\beta_{7} \Delta S_{C, t}+\beta_{8} \Delta K_{C, t}+\varepsilon_{t}$.

For every calendar month, we form value-weighted quitile portfolios based on the size of the loadings of either crude or market skewness innovations. The skewness premia (or lack of it) is determined by the size of the Jesen's alphas respected to the Carhart's four factor model augmented by the return of crude oil futures in the subsequent month. This table reports the monthly alphas, and average returns. Statistics in [ ] are Newey-West t-statistics elsewhere and regular t-statistics for the (5-1) portfolio. The superscript $^{* * *},{ }^{* *}$, and ${ }^{*}$ represents significance at $1 \%, 5 \%$ and $10 \%$, respectively.

\begin{tabular}{|c|c|c|c|c|c|c|}
\hline \multirow[b]{2}{*}{ Sorting Statistic } & \multicolumn{6}{|c|}{ Quintile Porfolio } \\
\hline & 1 & 2 & 3 & 4 & 5 & $5-1$ \\
\hline \multicolumn{7}{|l|}{ Panel A: Crude Oil } \\
\hline Skewness Beta (Univariate) & $\begin{array}{r}-0.293^{* * *} \\
{[-39.26]}\end{array}$ & $\begin{array}{r}-0.074^{* * *} \\
{[-33.07]}\end{array}$ & $\begin{array}{l}-0.001 \\
{[-0.72]}\end{array}$ & $\begin{array}{r}0.071^{* * *} \\
{[33.65]}\end{array}$ & $\begin{array}{r}0.299^{* * *} \\
{[37.89]}\end{array}$ & $\begin{array}{r}0.592^{* * *} \\
{[82.01]}\end{array}$ \\
\hline Average Return & $\begin{array}{l}1.288 \\
{[1.49}\end{array}$ & $\begin{array}{r}1.651^{* *} \\
{[2.57]}\end{array}$ & $\begin{array}{r}1.591^{* * *} \\
{[2.62]}\end{array}$ & $\begin{array}{l}0.948 \\
{[1.39]}\end{array}$ & $\begin{array}{r}2.908^{* * *} \\
{[3.18]}\end{array}$ & $\begin{array}{l}1.620 \\
{[1.35]}\end{array}$ \\
\hline Augument Carhart alpha & $\begin{array}{r}-1.185^{* *} \\
{[-2.23]}\end{array}$ & $\begin{array}{r}-0.747^{*} \\
{[-1.67]}\end{array}$ & $\begin{array}{l}-0.193 \\
{[-0.36]}\end{array}$ & $\begin{array}{l}-0.923 \\
{[-1.54]}\end{array}$ & $\begin{array}{l}0.948 \\
{[1.19]}\end{array}$ & $\begin{array}{r}2.133^{* *} \\
{[2.25]}\end{array}$ \\
\hline Skewness Beta (Multivariate) & $\begin{array}{r}-0.520^{* * *} \\
{[-5.55]}\end{array}$ & $\begin{array}{r}-0.098^{* * *} \\
{[-29.77]}\end{array}$ & $\begin{array}{l}-0.003 \\
{[-1.13]}\end{array}$ & $\begin{array}{r}0.091^{* * *} \\
{[35.17]}\end{array}$ & $\begin{array}{r}0.404^{* * *} \\
{[25.37]}\end{array}$ & $\begin{array}{r}0.924^{* * *} \\
{[9.80]}\end{array}$ \\
\hline Average Return & $\begin{array}{l}1.373 \\
{[1.56]}\end{array}$ & $\begin{array}{r}1.707^{* *} \\
{[2.53]}\end{array}$ & $\begin{array}{r}1.549^{* *} \\
{[2.56]}\end{array}$ & $\begin{array}{r}1.262^{*} \\
{[1.92]}\end{array}$ & $\begin{array}{r}2.305^{* * *} \\
{[2.65]}\end{array}$ & $\begin{array}{l}0.932 \\
{[0.79]}\end{array}$ \\
\hline Augument Carhart alpha & $\begin{array}{r}-1.190^{* *} \\
{[-2.20]}\end{array}$ & $\begin{array}{l}-0.465 \\
{[-1.03]}\end{array}$ & $\begin{array}{l}-0.369 \\
{[-0.85]}\end{array}$ & $\begin{array}{l}-0.733 \\
{[-1.22]}\end{array}$ & $\begin{array}{l}0.136 \\
{[0.15]}\end{array}$ & $\begin{array}{l}1.327 \\
{[1.28]}\end{array}$ \\
\hline Panel B: S\&P 500 & & & & & & \\
\hline Skewness Beta (Univariate) & $\begin{array}{r}-0.095^{* * *} \\
{[-39.03]}\end{array}$ & $\begin{array}{r}-0.024^{* * *} \\
{[-39.51]}\end{array}$ & $\begin{array}{r}-0.001^{* *} \\
{[-1.96]}\end{array}$ & $\begin{array}{r}0.022^{* * *} \\
{[35.82]}\end{array}$ & $\begin{array}{r}0.094^{* * *} \\
{[36.54]}\end{array}$ & $\begin{array}{r}0.189^{* * *} \\
{[84.10]}\end{array}$ \\
\hline Average Return & $\begin{array}{r}1.728^{* *} \\
{[2.06]}\end{array}$ & $\begin{array}{r}1.606^{* *} \\
{[2.40]}\end{array}$ & $\begin{array}{r}1.331^{* *} \\
{[2.18]}\end{array}$ & $\begin{array}{r}1.562^{* *} \\
{[2.37]}\end{array}$ & $\begin{array}{r}2.141^{* * *} \\
{[2.60]}\end{array}$ & $\begin{array}{l}0.413 \\
{[0.37]}\end{array}$ \\
\hline Augument Carhart alpha & $\begin{array}{l}-0.225 \\
{[-0.43]}\end{array}$ & $\begin{array}{l}0.012 \\
{[0.02]}\end{array}$ & $\begin{array}{l}-0.617 \\
{[-1.37]}\end{array}$ & $\begin{array}{r}-0.889^{*} \\
{[-1.71]}\end{array}$ & $\begin{array}{l}0.289 \\
{[0.47]}\end{array}$ & $\begin{array}{l}0.514 \\
{[0.54]}\end{array}$ \\
\hline Skewness Beta (Multivariate) & $\begin{array}{r}-0.205^{* * *} \\
\quad[-28.32]\end{array}$ & $\begin{array}{r}-0.048^{* * *} \\
{[-37.59]}\end{array}$ & $\begin{array}{l}0.001 \\
{[0.49]}\end{array}$ & $\begin{array}{r}0.048^{* * *} \\
{[37.16]}\end{array}$ & $\begin{array}{r}0.213^{* * *} \\
{[22.04]}\end{array}$ & $\begin{array}{r}0.418^{* * *} \\
{[40.35]}\end{array}$ \\
\hline Average Return & $\begin{array}{r}1.769^{* *} \\
{[2.11]}\end{array}$ & $\begin{array}{r}1.170^{*} \\
{[1.76]}\end{array}$ & $\begin{array}{r}1.459^{* *} \\
{[2.31]}\end{array}$ & $\begin{array}{r}2.116^{* * *} \\
{[3.20]}\end{array}$ & $\begin{array}{r}2.432^{* * *} \\
{[2.60]}\end{array}$ & $\begin{array}{l}0.663 \\
{[0.56]}\end{array}$ \\
\hline Augument Carhart alpha & $\begin{array}{l}0.093 \\
{[0.15]}\end{array}$ & $\begin{array}{l}-0.577 \\
{[-1.17]}\end{array}$ & $\begin{array}{l}-0.245 \\
{[-0.51]}\end{array}$ & $\begin{array}{l}0.010 \\
{[0.02]}\end{array}$ & $\begin{array}{l}0.956 \\
{[1.23]}\end{array}$ & $\begin{array}{l}0.863 \\
{[0.86]}\end{array}$ \\
\hline
\end{tabular}




\section{Table A4: Portfolios Sorted by Skewness Loadings: 2007-2011}

Monthly regressions for each stock in the sample are estimated to separately obtain the loadings on crude and S\&P 500 skewness innovations. The regression equations are (univariate):

$E R_{i, t}=\alpha+\beta_{1} E R_{M, t}+\beta_{2} R_{C, t}+\beta_{S}^{S P} \Delta S_{S P, t}+\varepsilon_{t}$, and $E R_{i, t}=\alpha+\beta_{1} E R_{M, t}+\beta_{2} R_{C, t}+\beta_{S}^{C} \Delta S_{C, t}+\varepsilon_{t}$

and (multivariate):

$E R_{i, t}=\alpha+\beta_{1} E R_{M, t}+\beta_{2} \Delta V_{S P, t}+\beta_{3} \Delta S_{S P, t}+\beta_{4} \Delta K_{S P, t}+\beta_{5} R_{C, t}+\beta_{6} \Delta V_{C, t}+\beta_{7} \Delta S_{C, t}+\beta_{8} \Delta K_{C, t}+\varepsilon_{t}$.

For every calendar month, we form value-weighted quitile portfolios based on the size of the loadings of either crude or market skewness innovations. The skewness premia (or lack of it) is determined by the size of the Jesen's alphas respected to the Carhart's four factor model augmented by the return of crude oil futures in the subsequent month. This table reports the monthly alphas, and average returns. Statistics in [ ] are Newey-West t-statistics elsewhere and regular t-statistics for the (5-1) portfolio. The superscript ${ }^{* * *},{ }^{* *}$, and ${ }^{*}$ represents significance at $1 \%, 5 \%$ and $10 \%$, respectively.

\begin{tabular}{|c|c|c|c|c|c|c|}
\hline \multirow[b]{2}{*}{ Sorting Statistic } & \multicolumn{6}{|c|}{ Quintile Porfolio } \\
\hline & 1 & 2 & 3 & 4 & 5 & $5-1$ \\
\hline \multicolumn{7}{|l|}{ Panel A: Crude Oil } \\
\hline Skewness Beta (Univariate) & $\begin{array}{r}-0.328 * * * \\
{[-19.09]}\end{array}$ & $\begin{array}{r}-0.092 * * * \\
{[-16.74]}\end{array}$ & $\begin{array}{l}-0.004 \\
{[-1.30]}\end{array}$ & $\begin{array}{r}0.082 * * * \\
{[17.98]}\end{array}$ & $\begin{array}{r}0.321 * * * \\
{[15.79]}\end{array}$ & $\begin{array}{r}0.649 * * * \\
{[35.69]}\end{array}$ \\
\hline Average Return & $\begin{array}{l}0.531 \\
{[0.29]}\end{array}$ & $\begin{array}{l}1.445 \\
{[0.99]}\end{array}$ & $\begin{array}{l}1.526 \\
{[1.15]}\end{array}$ & $\begin{array}{l}1.047 \\
{[0.77]}\end{array}$ & $\begin{array}{l}0.941 \\
{[0.54]}\end{array}$ & $\begin{array}{l}0.410 \\
{[0.15]}\end{array}$ \\
\hline Augument Carhart alpha & $\begin{array}{l}-0.193 \\
{[-0.20]}\end{array}$ & $\begin{array}{l}0.314 \\
{[0.48]}\end{array}$ & $\begin{array}{l}0.816 \\
{[1.30]}\end{array}$ & $\begin{array}{l}-0.116 \\
{[-0.16]}\end{array}$ & $\begin{array}{r}-1.173 * \\
{[-1.80]}\end{array}$ & $\begin{array}{l}-0.980 \\
{[-0.76]}\end{array}$ \\
\hline Skewness Beta (Multivariate) & $\begin{array}{r}-0.486 * * * \\
{[-15.05]}\end{array}$ & $\begin{array}{r}-0.111 * * * \\
{[-17.87]}\end{array}$ & $\begin{array}{r}0.022 * * * \\
{[3.64]}\end{array}$ & $\begin{array}{r}0.151 * * * \\
{[14.66]}\end{array}$ & $\begin{array}{r}0.496 * * * \\
{[15.71]}\end{array}$ & $\begin{array}{r}0.982 * * * \\
{[35.81]}\end{array}$ \\
\hline Average Return & $\begin{array}{l}0.764 \\
{[0.42]}\end{array}$ & $\begin{array}{l}0.632 \\
{[0.44]}\end{array}$ & $\begin{array}{l}1.557 \\
{[1.28]}\end{array}$ & $\begin{array}{r}1.392 \\
{[0.93]}\end{array}$ & $\begin{array}{r}1.037 \\
{[0.59]}\end{array}$ & $\begin{array}{l}0.272 \\
{[0.10]}\end{array}$ \\
\hline Augument Carhart alpha & $\begin{array}{l}-0.315 \\
{[-0.30]}\end{array}$ & $\begin{array}{l}0.026 \\
{[0.03]}\end{array}$ & $\begin{array}{l}0.572 \\
{[0.96]}\end{array}$ & $\begin{array}{l}0.407 \\
{[0.59]}\end{array}$ & $\begin{array}{l}-0.458 \\
{[-0.74]}\end{array}$ & $\begin{array}{l}-0.143 \\
{[-0.12]}\end{array}$ \\
\hline \multicolumn{7}{|l|}{ Panel B: S\&P 500} \\
\hline Skewness Beta (Univariate) & $\begin{array}{r}-0.073 * * * \\
{[-19.17]}\end{array}$ & $\begin{array}{r}-0.018 * * * \\
{[-16.97]}\end{array}$ & $\begin{array}{l}0.001 \\
{[1.41]}\end{array}$ & $\begin{array}{r}0.020 * * * \\
{[18.60]}\end{array}$ & $\begin{array}{r}0.082 * * * \\
{[10.10]}\end{array}$ & $\begin{array}{r}0.155 * * * \\
{[19.46]}\end{array}$ \\
\hline Average Return & $\begin{array}{l}1.304 \\
{[0.71]}\end{array}$ & $\begin{array}{l}1.299 \\
{[0.87]}\end{array}$ & $\begin{array}{l}1.667 \\
{[1.32]}\end{array}$ & $\begin{array}{r}0.69 \\
{[0.47]}\end{array}$ & $\begin{array}{l}1.937 \\
{[1.05]}\end{array}$ & $\begin{array}{l}0.632 \\
{[0.23]}\end{array}$ \\
\hline Augument Carhart alpha & $\begin{array}{l}0.307 \\
{[0.30]}\end{array}$ & $\begin{array}{l}0.354 \\
{[0.46]}\end{array}$ & $\begin{array}{l}0.449 \\
{[0.72]}\end{array}$ & $\begin{array}{l}0.440 \\
{[0.65]}\end{array}$ & $\begin{array}{l}0.257 \\
{[0.36]}\end{array}$ & $\begin{array}{l}-0.049 \\
{[-0.04]}\end{array}$ \\
\hline Skewness Beta (Multivariate) & $\begin{array}{r}-0.166 * * * \\
{[-14.49]}\end{array}$ & $\begin{array}{r}-0.044 * * * \\
{[-21.14]}\end{array}$ & $\begin{array}{l}-0.002 \\
{[-0.98]}\end{array}$ & $\begin{array}{r}0.043 * * * \\
{[20.12]}\end{array}$ & $\begin{array}{r}0.176 * * * \\
{[18.60]}\end{array}$ & $\begin{array}{r}0.342 * * * \\
{[28.00]}\end{array}$ \\
\hline Average Return & $\begin{array}{l}0.922 \\
{[0.54]}\end{array}$ & $\begin{array}{l}1.451 \\
{[0.99]}\end{array}$ & $\begin{array}{l}1.007 \\
{[0.81]}\end{array}$ & $\begin{array}{l}0.433 \\
{[0.30]}\end{array}$ & $\begin{array}{l}1.392 \\
{[0.75]}\end{array}$ & $\begin{array}{l}0.470 \\
{[0.18]}\end{array}$ \\
\hline Augument Carhart alpha & $\begin{array}{l}-0.095 \\
{[-0.11]}\end{array}$ & $\begin{array}{l}0.012 \\
{[0.02]}\end{array}$ & $\begin{array}{l}0.542 \\
{[0.82]}\end{array}$ & $\begin{array}{l}-0.458 \\
{[-0.62]}\end{array}$ & $\begin{array}{l}0.105 \\
{[0.16]}\end{array}$ & $\begin{array}{l}0.200 \\
{[0.15]}\end{array}$ \\
\hline
\end{tabular}




\section{Table A5: Portfolios Sorted by Kurtosis Loadings: 1996-2006}

Monthly regressions for each stock in the sample are estimated to separately obtain the loadings on crude and S\&P 500 Kurtosis innovations. The regression equations are (univariate):

$E R_{i, t}=\alpha+\beta_{1} E R_{M, t}+\beta_{2} R_{C, t}+\beta_{K}^{S P} \Delta K_{S P, t}+\varepsilon_{t}$, and $E R_{i, t}=\alpha+\beta_{1} E R_{M, t}+\beta_{2} R_{C, t}+\beta_{K}^{C} \Delta K_{C, t}+\varepsilon_{t}$

and (multivariate):

$E R_{i, t}=\alpha+\beta_{1} E R_{M, t}+\beta_{2} \Delta V_{S P, t}+\beta_{3} \Delta S_{S P, t}+\beta_{4} \Delta K_{S P, t}+\beta_{5} R_{C, t}+\beta_{6} \Delta V_{C, t}+\beta_{7} \Delta S_{C, t}+\beta_{8} \Delta K_{C, t}+\varepsilon_{t}$.

For every calendar month, we form value-weighted quitile portfolios based on the size of the loadings of either crude volatility or market kurtosis innovations. The kurtosis premia (or lack of it) is determined by the size of the Jesen's alphas respected to the Carhart's four factor model augmented by the return of crude oil futures in the subsequent month. This table reports the monthly alphas, and average returns. Statistics in [ ] are Newey-West t-statistics elsewhere and regular t-statistics for the (5-1) portfolio. The superscript ${ }^{* * *},{ }^{* *}$, and ${ }^{*}$ represents significance at $1 \%, 5 \%$ and $10 \%$, respectively.

\begin{tabular}{|c|c|c|c|c|c|c|}
\hline \multirow[b]{2}{*}{ Sorting Statistic } & \multicolumn{6}{|c|}{ Quintile Porfolio } \\
\hline & 1 & 2 & 3 & 4 & 5 & $5-1$ \\
\hline \multicolumn{7}{|l|}{ Panel A: Crude Oil } \\
\hline Kurtosis Beta (Univariate) & $\begin{array}{r}-0.221^{* * *} \\
{[-38.35]}\end{array}$ & $\begin{array}{r}-0.057^{* * *} \\
{[-36.34]}\end{array}$ & $\begin{array}{r}-0.002^{* *} \\
{[-1.98]}\end{array}$ & $\begin{array}{r}0.053^{* * *} \\
{[34.33]}\end{array}$ & $\begin{array}{r}0.225^{* * *} \\
{[36.12]}\end{array}$ & $\begin{array}{r}0.447^{* * *} \\
{[85.65]}\end{array}$ \\
\hline Average Return & $\begin{array}{l}1.127 \\
{[1.19]}\end{array}$ & $\begin{array}{r}1.634^{* *} \\
{[2.44]}\end{array}$ & $\begin{array}{r}1.363^{* *} \\
{[2.24]}\end{array}$ & $\begin{array}{r}1.623^{* *} \\
{[2.45]}\end{array}$ & $\begin{array}{r}1.991^{* *} \\
{[2.40]}\end{array}$ & $\begin{array}{l}0.863 \\
{[0.72]}\end{array}$ \\
\hline Augmented Carhart alpha & $\begin{array}{l}-0.312 \\
{[-0.49]}\end{array}$ & $\begin{array}{l}-0.854 \\
{[-1.42}\end{array}$ & $\begin{array}{l}-0.519 \\
{[-1.09}\end{array}$ & $\begin{array}{l}-0.300 \\
{[-0.65]}\end{array}$ & $\begin{array}{l}-0.351 \\
{[-0.58]}\end{array}$ & $\begin{array}{l}-0.039 \\
{[-0.04]}\end{array}$ \\
\hline Kurtosis Beta (Multivariate) & $\begin{array}{r}-0.353^{* * *} \\
{[-5.82]}\end{array}$ & $\begin{array}{r}-0.078^{* * *} \\
{[-36.65]}\end{array}$ & $\begin{array}{r}-0.005^{* * *} \\
{[-2.81]}\end{array}$ & $\begin{array}{r}0.068^{* * *} \\
{[32.94]}\end{array}$ & $\begin{array}{r}0.298^{* * *} \\
{[36.88]}\end{array}$ & $\begin{array}{r}0.651^{* * *} \\
{[10.71]}\end{array}$ \\
\hline Average Return & $\begin{array}{r}1.625^{*} \\
{[1.72]}\end{array}$ & $\begin{array}{r}1.795^{* * *} \\
{[2.74]}\end{array}$ & $\begin{array}{c}1.174^{*} \\
{[1.95]}\end{array}$ & $\begin{array}{r}1.715^{* * *} \\
{[2.62]}\end{array}$ & $\begin{array}{r}1.652^{* *} \\
{[2.03]}\end{array}$ & $\begin{array}{l}0.027 \\
{[0.02]}\end{array}$ \\
\hline Augmented Carhart alpha & $\begin{array}{l}-0.128 \\
{[-0.19]}\end{array}$ & $\begin{array}{l}-0.676 \\
{[-1.35]}\end{array}$ & $\begin{array}{r}-0.825^{*} \\
{[-1.79]}\end{array}$ & $\begin{array}{l}-0.244 \\
{[-0.48]}\end{array}$ & $\begin{array}{l}0.468 \\
{[0.72]}\end{array}$ & $\begin{array}{l}0.595 \\
{[0.57]}\end{array}$ \\
\hline Panel B: S\&P 500 & & & & & & \\
\hline Kurtosis Beta (Univariate) & $\begin{array}{r}-0.025^{* * *} \\
{[-28.88]}\end{array}$ & $\begin{array}{r}-0.006^{* * *} \\
{[-29.85]}\end{array}$ & $\begin{array}{r}0.000^{* * *} \\
{[3.34]}\end{array}$ & $\begin{array}{r}0.007^{* * *} \\
{[31.17]}\end{array}$ & $\begin{array}{r}0.026^{* * *} \\
{[27.75]}\end{array}$ & $\begin{array}{r}0.051^{* * *} \\
{[64.02]}\end{array}$ \\
\hline Average Return & $\begin{array}{r}1.692^{*} \\
{[1.94]}\end{array}$ & $\begin{array}{r}1.137^{*} \\
{[1.66]}\end{array}$ & $\begin{array}{r}1.569^{* * * *} \\
{[2.62]}\end{array}$ & $\begin{array}{r}1.451^{* *} \\
{[2.29]}\end{array}$ & $\begin{array}{r}2.675^{* * *} \\
{[2.72]}\end{array}$ & $\begin{array}{l}0.984 \\
{[0.81]}\end{array}$ \\
\hline Augmented Carhart alpha & $\begin{array}{l}-0.209 \\
{[-0.30]}\end{array}$ & $\begin{array}{r}-1.304^{* * *} \\
{[-2.65]}\end{array}$ & $\begin{array}{l}-0.083 \\
{[-0.16]}\end{array}$ & $\begin{array}{l}-0.231 \\
{[-0.53]}\end{array}$ & $\begin{array}{l}0.074 \\
{[0.10]}\end{array}$ & $\begin{array}{l}0.283 \\
{[0.26]}\end{array}$ \\
\hline Kurtosis Beta (Multivariate) & $\begin{array}{r}-0.052^{* * *} \\
{[-21.19]}\end{array}$ & $\begin{array}{r}-0.012^{* * *} \\
{[-33.40]}\end{array}$ & $\begin{array}{r}0.001^{* * * *} \\
{[2.73]}\end{array}$ & $\begin{array}{r}0.013^{* * *} \\
{[33.40]}\end{array}$ & $\begin{array}{r}0.059^{* * *} \\
{[15.47]}\end{array}$ & $\begin{array}{r}0.111^{* * *} \\
{[27.54]}\end{array}$ \\
\hline Average Return & $\begin{array}{l}1.263 \\
{[1.46]}\end{array}$ & $\begin{array}{r}1.291^{*} \\
{[1.91]}\end{array}$ & $\begin{array}{r}1.562^{* *} \\
{[2.57]}\end{array}$ & $\begin{array}{r}1.837^{* * *} \\
{[2.82]}\end{array}$ & $\begin{array}{r}2.294^{* *} \\
{[2.33]}\end{array}$ & $\begin{array}{l}1.030 \\
{[0.85]}\end{array}$ \\
\hline Augmented Carhart alpha & $\begin{array}{l}-0.787 \\
{[-1.21]}\end{array}$ & $\begin{array}{l}-0.723 \\
{[-1.42]}\end{array}$ & $\begin{array}{l}-0.217 \\
{[-0.50]}\end{array}$ & $\begin{array}{l}-0.229 \\
{[-0.42]}\end{array}$ & $\begin{array}{l}0.477 \\
{[0.59]}\end{array}$ & $\begin{array}{l}1.264 \\
{[1.21]}\end{array}$ \\
\hline
\end{tabular}




\section{Table A6: Portfolios Sorted by Kurtosis Loadings: 2007-2011}

Monthly regressions for each stock in the sample are estimated to separately obtain the loadings on crude and S\&P 500 Kurtosis innovations. The regression equations are (univariate):

$E R_{i, t}=\alpha+\beta_{1} E R_{M, t}+\beta_{2} R_{C, t}+\beta_{K}^{S P} \Delta K_{S P, t}+\varepsilon_{t}$, and $E R_{i, t}=\alpha+\beta_{1} E R_{M, t}+\beta_{2} R_{C, t}+\beta_{K}^{C} \Delta K_{C, t}+\varepsilon_{t}$

and (multivariate):

$E R_{i, t}=\alpha+\beta_{1} E R_{M, t}+\beta_{2} \Delta V_{S P, t}+\beta_{3} \Delta S_{S P, t}+\beta_{4} \Delta K_{S P, t}+\beta_{5} R_{C, t}+\beta_{6} \Delta V_{C, t}+\beta_{7} \Delta S_{C, t}+\beta_{8} \Delta K_{C, t}+\varepsilon_{t}$.

For every calendar month, we form value-weighted quitile portfolios based on the size of the loadings of either crude volatility or market kurtosis innovations. The kurtosis premia (or lack of it) is determined by the size of the Jesen's alphas respected to the Carhart's four factor model augmented by the return of crude oil futures in the subsequent month. This table reports the monthly alphas, and average returns. Statistics in [ ] are Newey-West t-statistics elsewhere and regular t-statistics for the (5-1) portfolio. The superscript ${ }^{* *},{ }^{* *}$, and ${ }^{*}$ represents significance at $1 \%, 5 \%$ and $10 \%$, respectively.

\begin{tabular}{|c|c|c|c|c|c|c|}
\hline \multirow[b]{2}{*}{ Sorting Statistic } & \multicolumn{6}{|c|}{ Quintile Porfolio } \\
\hline & 1 & 2 & 3 & 4 & 5 & $5-1$ \\
\hline \multicolumn{7}{|l|}{ Panel A: Crude Oil } \\
\hline Kurtosis Beta (Univariate) & $\begin{array}{r}-0.147^{* * *} \\
{[-18.58]}\end{array}$ & $\begin{array}{r}-0.030^{* * *} \\
{[-14.48]}\end{array}$ & $\begin{array}{r}0.011^{* * *} \\
{[5.75]}\end{array}$ & $\begin{array}{r}0.055^{* * *} \\
{[19.22]}\end{array}$ & $\begin{array}{r}0.184^{* * *} \\
{[20.18]}\end{array}$ & $\begin{array}{r}0.331^{* * *} \\
{[41.97]}\end{array}$ \\
\hline Average Return & $\begin{array}{l}1.116 \\
{[0.64]}\end{array}$ & $\begin{array}{l}0.898 \\
{[0.70]}\end{array}$ & $\begin{array}{l}0.966 \\
{[0.71]}\end{array}$ & $\begin{array}{l}1.465 \\
{[0.95]}\end{array}$ & $\begin{array}{l}1.239 \\
{[0.66]}\end{array}$ & $\begin{array}{l}0.123 \\
{[0.05]}\end{array}$ \\
\hline Augmented Carhart alpha & $\begin{array}{l}-0.430 \\
{[-0.52]}\end{array}$ & $\begin{array}{l}0.068 \\
{[0.10]}\end{array}$ & $\begin{array}{l}0.443 \\
{[0.70]}\end{array}$ & $\begin{array}{l}-0.109 \\
{[-0.15]}\end{array}$ & $\begin{array}{l}0.413 \\
{[0.37]}\end{array}$ & $\begin{array}{l}0.843 \\
{[0.63]}\end{array}$ \\
\hline Kurtosis Beta (Multivariate) & $\begin{array}{r}-0.231^{* * *} \\
{[-17.34]}\end{array}$ & $\begin{array}{r}-0.051^{* * *} \\
{[-16.86]}\end{array}$ & $\begin{array}{r}0.018^{* * *} \\
{[5.37]}\end{array}$ & $\begin{array}{r}0.089^{* * *} \\
{[16.49]}\end{array}$ & $\begin{array}{r}0.277^{* * *} \\
{[18.54]}\end{array}$ & $\begin{array}{r}0.508^{* * *} \\
{[41.74]}\end{array}$ \\
\hline Average Return & $\begin{array}{r}1.023 \\
{[0.62]}\end{array}$ & $\begin{array}{r}1.289 \\
{[1.01]}\end{array}$ & $\begin{array}{l}1.396 \\
{[1.06]}\end{array}$ & $\begin{array}{l}0.361 \\
{[0.24]}\end{array}$ & $\begin{array}{l}1.072 \\
{[0.56]}\end{array}$ & $\begin{array}{l}0.049 \\
{[0.02]}\end{array}$ \\
\hline Augmented Carhart alpha & $\begin{array}{l}-0.875 \\
{[-0.94]}\end{array}$ & $\begin{array}{l}0.016 \\
{[0.03]}\end{array}$ & $\begin{array}{l}0.498 \\
{[1.07]}\end{array}$ & $\begin{array}{l}-0.275 \\
{[-0.31]}\end{array}$ & $\begin{array}{l}0.540 \\
{[0.55]}\end{array}$ & $\begin{array}{l}1.415 \\
{[0.99]}\end{array}$ \\
\hline Panel B: S\&P 500 & & & & & & \\
\hline Kurtosis Beta (Univariate) & $\begin{array}{r}-0.020^{* * *} \\
{[-15.15]}\end{array}$ & $\begin{array}{r}-0.006^{* * *} \\
{[-13.76]}\end{array}$ & $\begin{array}{r}-0.001^{*} \\
{[-1.82]}\end{array}$ & $\begin{array}{r}0.005^{* * *} \\
{[12.61]}\end{array}$ & $\begin{array}{r}0.023^{* * *} \\
{[9.99]}\end{array}$ & $\begin{array}{r}0.043^{* * *} \\
{[20.13]}\end{array}$ \\
\hline Average Return & $\begin{array}{l}2.069 \\
{[1.14]}\end{array}$ & $\begin{array}{l}1.722 \\
{[1.20]}\end{array}$ & $\begin{array}{l}0.681 \\
{[0.51]}\end{array}$ & $\begin{array}{l}1.065 \\
{[0.80]}\end{array}$ & $\begin{array}{l}0.753 \\
{[0.42]}\end{array}$ & $\begin{array}{l}-1.316 \\
{[-0.50]}\end{array}$ \\
\hline Augmented Carhart alpha & $\begin{array}{l}0.551 \\
{[0.67]}\end{array}$ & $\begin{array}{l}0.277 \\
{[0.42]}\end{array}$ & $\begin{array}{l}0.514 \\
{[0.79]}\end{array}$ & $\begin{array}{l}0.296 \\
{[0.39]}\end{array}$ & $\begin{array}{l}0.533 \\
{[0.53]}\end{array}$ & $\begin{array}{l}-0.018 \\
{[-0.01]}\end{array}$ \\
\hline Kurtosis Beta (Multivariate) & $\begin{array}{r}-0.040^{* * *} \\
{[-13.59]}\end{array}$ & $\begin{array}{r}-0.011^{* * *} \\
{[-15.93]}\end{array}$ & $\begin{array}{r}0 \\
{[-0.26]}\end{array}$ & $\begin{array}{r}0.011^{* * *} \\
{[15.00]}\end{array}$ & $\begin{array}{r}0.047^{* * *} \\
{[13.59]}\end{array}$ & $\begin{array}{r}0.087^{* * *} \\
{[25.75]}\end{array}$ \\
\hline Average Return & $\begin{array}{l}2.029 \\
{[1.15]}\end{array}$ & $\begin{array}{r}1.286 \\
{[0.90]}\end{array}$ & $\begin{array}{l}0.798 \\
{[0.59]}\end{array}$ & $\begin{array}{l}0.681 \\
{[0.47]}\end{array}$ & $\begin{array}{r}0.670 \\
{[0.36]}\end{array}$ & $\begin{array}{l}-1.359 \\
{[-0.51]}\end{array}$ \\
\hline Augmented Carhart alpha & $\begin{array}{l}0.080 \\
{[0.09]}\end{array}$ & $\begin{array}{l}-0.069 \\
{[-0.12]}\end{array}$ & $\begin{array}{l}0.528 \\
{[0.82]}\end{array}$ & $\begin{array}{l}0.209 \\
{[0.28]}\end{array}$ & $\begin{array}{l}-0.657 \\
{[-0.85]}\end{array}$ & $\begin{array}{l}-0.737 \\
{[-0.52]}\end{array}$ \\
\hline
\end{tabular}

